\title{
Pelagic nutrient and energy transfer during spring in the open and coastal Skagerrak
}

\author{
R. Rosenberg ${ }^{1}$, E. Dahl ${ }^{2}$, L. Edler ${ }^{3}$, L. Fyrberg ${ }^{4}$, E. Granéli ${ }^{3}$, W. Granéli ${ }^{5}$, \\ Å. Hagström ${ }^{6}$, O. Lindahl ${ }^{7}$, M. O. Matos ${ }^{3}$, K. Pettersson ${ }^{8}$, E. Sahlsten ${ }^{8}$, P. Tiselius ${ }^{1}$, \\ V. Turk ${ }^{9}$, J. Wikner ${ }^{6}$ \\ ${ }^{1}$ University of Göteborg, Marine Research Station at Kristineberg, S-450 32 Fiskebäckskil, Sweden \\ ${ }^{2}$ Flodevigen Biological Station, N-4800 Arendal, Norway \\ ${ }^{3}$ University of Lund, Department of Marine Ecology, S-221 00 Lund, Sweden \\ ${ }^{4}$ Swedish Meteorlogical and Hydrological Institute, S-403 14 Göteborg, Sweden \\ ${ }^{5}$ University of Lund, Department of Limnology, S-221 00 Lund, Sweden \\ ${ }^{6}$ University of Umeå, Department of Microbiology, S-901 87 Umeå, Sweden \\ ${ }^{7}$ Kristineberg Marine Biological Station, S-450 34 Fiskebäckskil, Sweden \\ ${ }^{8}$ University of Göteborg, Department of Microbiology, S-413 19 Göteborg, Sweden \\ ${ }^{9}$ Marine Biological Station, YU-66330 Piran, Yugoslavia
}

\begin{abstract}
In May 1987 multidisciplinary investigations focusing on diel variations were performed at 4 horizontally stratified (pycnocline at 5 to $12 \mathrm{~m}$ ) stations in the open Skagerrak (North Sea). Nutrients were lower above the pycnocline than below. Phytoplankton was numerically dominated by flagellates and monads indicating a regenerating plankton community, which was confirmed by the finding that about $80 \%$ of the nitrogen uptake in surface waters was as $\mathrm{NH}_{4}{ }^{+}$and urea, and about $20 \%$ was $\mathrm{NO}_{3}{ }^{-}$ Percentage of 'new' primary production (based on $\mathrm{NO}_{3}{ }^{-}$uptake) was similar to the percentage sedimentation rate (in C) of primary production (ca $20 \%$ ). Growth of bacteria and grazing on bacteria were systematically dependent on time of day above, in and below the pycnocline. Abundance of bacteria and nanoflagellates was not regularly dependent on time of day, but systematically elevated in the pycnocline, as was chlorophyll a. Zooplankton grazing in the surface water was highest at night and early morning. Benthic investigations indicated heterogeneity in the area. For comparison, samples of hydrography, nutrients, phytoplankton abundance and growth, and sedimentation. were investigated at the same time at a coastal station with horizontal stratification and slightly lower salinity. Here 'new' primary production was estimated to about $50 \%$ of total production, based on percentage sedimentation. Nitrogen seemed in general to be in deficit for primary production relative to phosphorus in surface waters both in the open and coastal Skagerrak, but exceptions could occur That nutrients were in surplus just below the shallow pycnocline shows, however, that those primary producers and bacteria which could utilize this reservoir had access to unlimited nutrient resources at that time. It was estimated that bacteria and flagellates made up $>50 \%$ of total pelagic respiration and consumed slightly more than the net primary production
\end{abstract}

\section{INTRODUCTION}

Hydrographic processes and nutrient concentrations are, in combination, steering abiotic factors for the development and function of pelagic communities. Ecological processes in pelagic communities are, however, poorly understood because of high complexity and variability. In the North Sea only a few investigations have dealt with pelagic communities in different hydrographic regimes and their authors (Holligan et al. 1984, Newell \& Linley 1984) have pointed to the important role of microheterotrophs as energy consumers and for the regeneration of nitrogen. In the Skagerrak (Fig. 1), where the North Sea extends between Norway and Denmark, 2 short-term studies were earlier performed concerning in particular the phytoplankton distribution; in August 1981 in relation to the doming of a seasonal thermocline (Pingree et al. 1982), and in April 1984 in relation to a frontal area at the Kattegat boarder (Richardson 1985). The hydrography of the Skagerrak was summarized by Svansson (1975). The general current system at the surface is cyclonal, i.e. the 'Jutland Current' moves eastward along the north Danish coast, and joins the north-flowing 'Baltic Current' off 


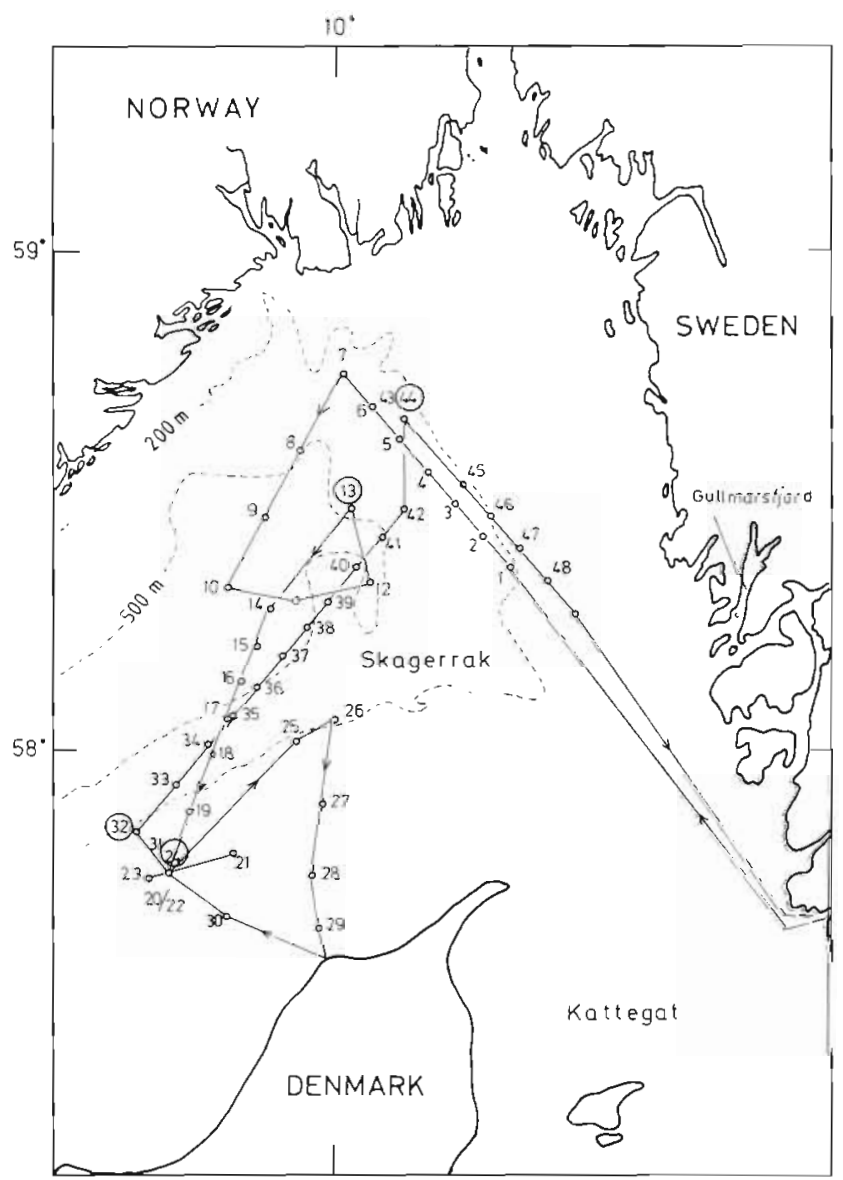

Fig. 1. Track plot of the cruise in the open Skagerrak with sampling stations and depth contours. 'Diel' stations are encircled. The coastal station in Gullmarsfjord is also indicated

the Swedish coast. This surface current then moves northwards towards Norway, bends to the west and moves towards the North Sea. In the southwestern Skagerrak oceanic water can be found up to the surface but is diluted with Baltic water in the eastern and northern parts (Larsson \& Rodhe 1979).

Earlier investigations suggest that nutrients are available in the surface water during the whole spring in central and eastern Skagerrak (Dahl \& Danielssen 1981, Richardson 1985). The spring 'bloom' begins in March (Dahl \& Danielssen 1981). From August to November 'new' nutrients $\left(\mathrm{NO}_{3}{ }^{-}\right)$seem to be available only at or below the pycnocline at ca $20 \mathrm{~m}$ depth and deeper (Larsson \& Rodhe 1979, Pingree et al. 1982, Foyn 1987)

The aim of the present investigation was to clarify how nutrient availability in these stratified waters interacts with the pelagic community, and how much of the primary production is recycled in the upper water mass as compared to the amount lost to deeper waters through sedimentation. With such an approach it should be possible to estimate the proportion of 'new' versus 'regenerated' nutrients used by the pelagic community (e.g. Eppley \& Peterson 1979, Wassmann 1986).

The investigation was carried out during 2 wk in May 1987 and comprised 48 stations in the open Skagerrak and one coastal station in Gullmarsfjord (Fig. 1). Based on hydrography and phytoplankton concentrations (CTD-profiles and fluorescence profiles) 4 horizontally stratified stations were selected in the open Skagerrak for $24 \mathrm{~h}$ diel studies.

The study includes the following parameters: CTDprofiles, nutrients $\left(\mathrm{PO}_{4}{ }^{3-}, \mathrm{NO}_{2}{ }^{-}, \mathrm{NO}_{3}{ }^{-}, \mathrm{NH}_{4}{ }^{+}\right.$, urea, total $\mathrm{P}$, total $\mathrm{N}$ ), oxygen concentrations and oxygen consumption, chlorophyll a (chl a), fluorescence profiles, phytoplankton (abundance, production), bacteria (abundance, production) heterotrophic flagellates (abundance, bacteria consumption), uptake of $\mathrm{NO}_{3}{ }^{-}$, $\mathrm{NH}_{4}{ }^{+}$and urea by phytoplankton $\left({ }^{15} \mathrm{~N}\right.$-studies) and concentrations of particulate nitrogen (PN) and particulate carbon (PC), alkaline phosphatase activity in phytoplankton, net zooplankton (abundance, consumption, egg production), sedimentation, sediment structure and benthic macrofauna. Most of these measurements were made every 6 th hour ( 5 times in $24 \mathrm{~h}$ ) and at all 4 stations. The study in Gullmarsfjord provides a comparison with the offshore situation and comprised analyses of CTD-profiles, nutrients, chl $a$, phytoplankton, oxygen and sedimentation.

\section{METHODS}

The investigation in the open Skagerrak was performed from RV 'Argos' on 11 to 22 May 1987. Profiles of CTD and chl a fluorescence were taken at the 48 stations shown in Fig. 1. Diel samplings were undertaken at Stn 13 (12 to 13 May), 24 (14 to 15 May), 32 (18 to 19 May) and 44 (20 to 21 May). Samplings were concentrated at the following times: 11:00, 17:00, 23:00, 05:00 and 11:00 h. The samples at Stn 13 at those hours were recorded as $13 \mathrm{~A}, 13 \mathrm{~B}, 13 \mathrm{C}, 13 \mathrm{D}$ and $13 \mathrm{E}$, respectively, and in a corresponding way for the other 3 'diel' stations. Samples in Gullmarsfjord were taken on 15. 19 and 21 May 1987

Sampling. Water samples were taken in relation to the vertical position of the pycnocline and to chl a distribution. Samplings were performed above, in, and below the pycnocline, which was well developed at all stations. In addition nutrients and oxygen consumption were analysed at 20 and $30 \mathrm{~m}$, and oxygen consumption also at 50 and $100 \mathrm{~m}$. Water samples were taken by a Rosette multibottle-array system (model 1015) or by a 301 Niskin bottle in conjunction with CTD analysis (Neil Brown). In almost all cases subsamples were 
withdrawn from the same water batch and used for all the various analyses at a particular depth.

Nutrient analysis. Total nitrogen (TN) and total phosphorus (TP) and $\mathrm{PO}_{4}{ }^{3-}$ were analysed in the water samples according to Valderrama (1981); $\mathrm{NO}_{2}{ }^{-}, \mathrm{NO}_{3}{ }^{-}$, $\mathrm{NH}_{4}{ }^{+}$and $\mathrm{SiO}_{2}$ according to Carlberg (1972).

For the ${ }^{15} \mathrm{~N}$-uptake experiments, analyses of $\mathrm{NO}_{3}{ }^{-}$, $\mathrm{NO}_{2}{ }^{-}$and urea were done automatically and analysis of $\mathrm{NH}_{4}{ }^{+}$manually according to Sahlsten et al. (1988).

Particulate carbon (PC) and nitrogen (PN) samples were collected on precombusted Whatman GF/F glass fibre filters and treated as described in Sahlsten et al. (1988). The surface water samples were in some cases post-fractionated for analyses of particles $<3 \mu \mathrm{m}$ by gravity-filtration through $3 \mu \mathrm{m}$ Nuclepore filters (Schleicher and Schüll filter holder, MO 142/0 standard model, $140 \mathrm{~mm}$ diameter).

Biomass estimation of plankton (including bacteria). Chl $a$ in vivo fluorescence was measured with a $Q$ meter fluorometer and calibrated to chl a from analysis of water samples as described in Edler (1979). Phytoplankton was counted from pooled samples from above the halocline and from one sample between the halocline and $20 \mathrm{~m}$ depth using the Utermöhl method. Heterotrophic bacteria and flagellates were stained with DAPI (Porter \& Feig 1980) and counted in an epifluorescence microscope.

Nitrogen uptake rates. The nitrogen uptake rates were determined after additions of $0.2 \mu \mathrm{mol} \mathrm{N} 1^{-1}$ of ${ }^{15} \mathrm{~N}$-labelled substrates of $\mathrm{NH}_{4}{ }^{+}, \mathrm{NO}_{3}{ }^{-}$or urea to $2.6 \mathrm{l}$ polycarbonate bottles. The diel experiments for determining the uptake rates of $\mathrm{NH}_{4}{ }^{+}, \mathrm{NO}_{3}{ }^{-}$, and urea were performed at Stns 32 and 44 . The incubations were carried out in deck-incubators covered with neutral density screens and cooled with running surface seawater and treatment of filters were as described in Sahlsten et al. (1988).

Primary production. Daily primary production in the open Skagerrak was estimated on 3 fractions: $0.2-3$ $\mu \mathrm{m}, 3-10 \mu \mathrm{m}$ and $>10 \mu \mathrm{m}$, using an incubator according to the method described in Ertebjerg \& Bresta (1984). Filters (Nuclepore) were treated as described by Larsson \& Hagström (1982). In Gullmarsfjord primary production was measured in situ at 10 depths down to $20 \mathrm{~m}$ by the ${ }^{14} \mathrm{C}$-technique using an incubation period of $4 \mathrm{~h}$ around noon according to Baltic Marine Biologists (1976). Daily production, including exudate, was estimated by linear extrapolation according to the total daily irradiation

Bacterial production. Bacterial production was measured with the ${ }^{3} \mathrm{H}$-thymidine method according to Fuhrman \& Azam (1982). Moles of thymidine incorporated were recalculated to cells produced with the factor $1.1 \times 10^{18}$ cells $\mathrm{mol}^{-1}$.

Predation rate on bacteria. Genetically marked minicells were added to a water sample to an initial concentration of $2 \times 10^{5}$ cells $\mathrm{ml}^{-1}$. The consumption of minicells was determinated according to Wikner et al. (1986) and recalculated to predation rate on bacteria with the minicell to pelagic bacteria ratio.

Alkaline phosphatase activity (APA). APA was measured on unfiltered samples according to the method in Petersson (1979) in order to determine if the phytoplankton showed signs of phosphate deficiency. In addition to the 'diel' Stns 32 and 44, APA was also measured at Stns $30,35,38,41,45,46,47$, and 48 (Fig. 1).

Zooplankton. Zooplankton were sampled at Stns 13 and 24 by vertical tows with a $200 \mu \mathrm{m}$ closing UNESCO WP-2 net and preserved in formaldehyde. Three depth intervals were sampled at Stn $24(0-10 \mathrm{~m}, 10-30 \mathrm{~m}$, and $30 \mathrm{~m}$-bottom), whereas at Stn 13 only the upper $15 \mathrm{~m}$ were sampled. Copepod grazing was determinated by the gut fluorescence method (Kiörboe et al. 1985) at 5 and $12 \mathrm{~m}$ depth every third hour over a $24 \mathrm{~h}$ period. For an independent estimate of ingestion of other food items than chl a-containing algae, copepod egg production was measured. Egg production was measured by incubating 1 to 8 adult female copepods collected at the surface in 11 plastic bottles filled with $64 \mu \mathrm{m}$ screened surface seawater for 24 to $36 \mathrm{~h}$. Copepod carbon ingestion, measured as gut fluorescence, was then calculated by using ambient carbon:chlorophyll ratios and from egg production rates, assuming a $33 \%$ gross production efficiency (Kiörboe et al. 1985). Details on methods and calculations are given elsewhere (Tiselius 1988).

Sedimentation. Sedimentation in the open Skagerrak was measured by short-term (1 d) deployment of anchored or free-floating cylindrical double sediment traps (Håkanson 1984) at 20 and $40 \mathrm{~m}$ depth at Stns 24, 32 and 44 . Particles were concentrated on precombusted GF/F filters, which were subsequently analysed for chl a (method in Edler 1979) and PN and PC using a Carlo Erba elemental analyzer. Sedimentation in Gullmarsfjord was measured by single cylindrical traps at $20,40,60$ and $110 \mathrm{~m}$ depth. The sampling period was $4 \mathrm{~d}$. The sampled material from each trap was used to determine the amount of particulate organic material (POM), particulate carbon (PC) and particulate nitrogen (PN) according to methods by Wassmann (1983).

Respiration. Seston respiration was measured according to the filter method of Comett \& Rigler (1986). Particulate material was concentrated on Gelman GN-6 $6^{\mathrm{TM}}$ filters (0.45 $\mu \mathrm{m}$ nominal pore size) through gentle suction filtration of 500 or $1000 \mathrm{ml}$ of seawater. Filters were incubated in darkness at the ambient temperature for $24 \mathrm{~h}$ in $60 \mathrm{ml}$ oxygen bottles filled with unfiltered water from the same depth. Controls were bottles with unused filters to which $200 \mu \mathrm{l}$ 
$4 \% \mathrm{HgCl}_{2}$ had been added. Measurements according to the Winkler method were made in duplicate or triplicate for each depth. There was no measurable change in the oxygen concentration in unpoisoned bottles without filters.

Benthic fauna. The benthic fauna was sampled by taking 3 hauls with a $0.1 \mathrm{~m}^{2}$ Smith-Mclntyre grab at each of Stns 24, 32 and 44. The material retained on a $1 \mathrm{~mm}$ sieve was preserved in $4 \%$ formaldehyde and animals were later picked out under $6 \times$ magnification. Biomass was estimated after blotting the animals on filter paper. Shannon-Wiener diversity $\mathrm{H}^{\prime}$ and evenness J' were calculated according to Pielou (1966). The organic content of the sediment was estimated in the top 0 to $2 \mathrm{~cm}$ in 2 or 3 hauls at each station after drying for $7 \mathrm{~d}$ in $80^{\circ} \mathrm{C}$ and then combusting for $5 \mathrm{~h}$ in $500^{\circ} \mathrm{C}$. Percent fines was measured by sieving the top sediment through a 50 um sieve after removing the organic material through addition of hydrogen peroxide (Buchanan \& Kain 1971).
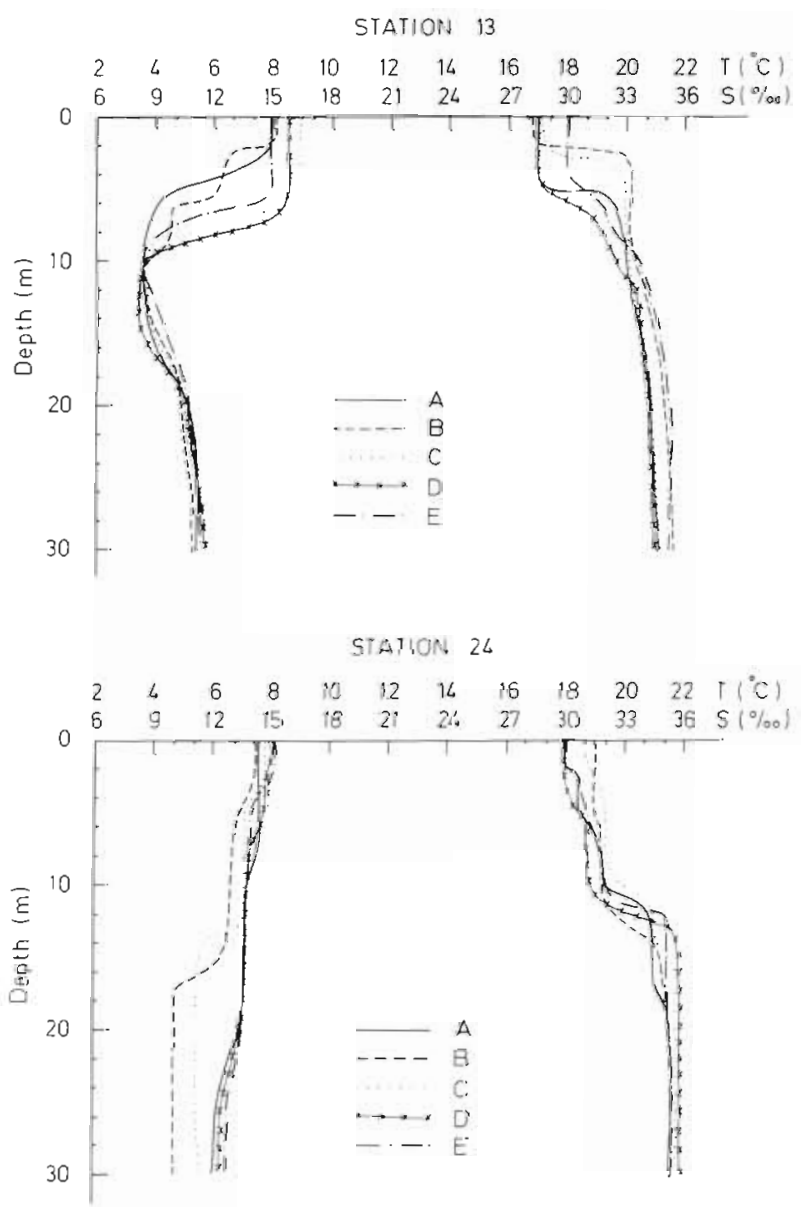

\section{RESULTS}

\section{Open Skagerrak}

\section{Hydrography and nutrients}

The surface salinity at the 4 'diel' stations ranged between 28 and $32 \%$, and the temperature between 7 and $10^{\circ} \mathrm{C}$ (Fig. 2). A strong pycnocline was found between 5 and $12 \mathrm{~m}$ at all 'diel' stations below which salinity stabilized at about $35 \%$, and temperature at 4 to $5^{\circ} \mathrm{C}$, except at $\operatorname{Stn} 24$. The diel variations of these parameters at Stns 24, 32 and 44 were small, but greater at $\mathrm{Stn} 13$. When examining the $5 \mathrm{~m}$ depth contour for the whole investigated area, it appeared that salinity was lower towards the Swedish coast; $<30 \%$ east of Stn 45 . Low surface-salinity water 28 to $29 \%$ ) was also found in a wedge reaching westward to Stn 13 during 12 and 13 May. The following week the surface salinity was $>30 \%$ in that area and west of $\mathrm{Stn}$
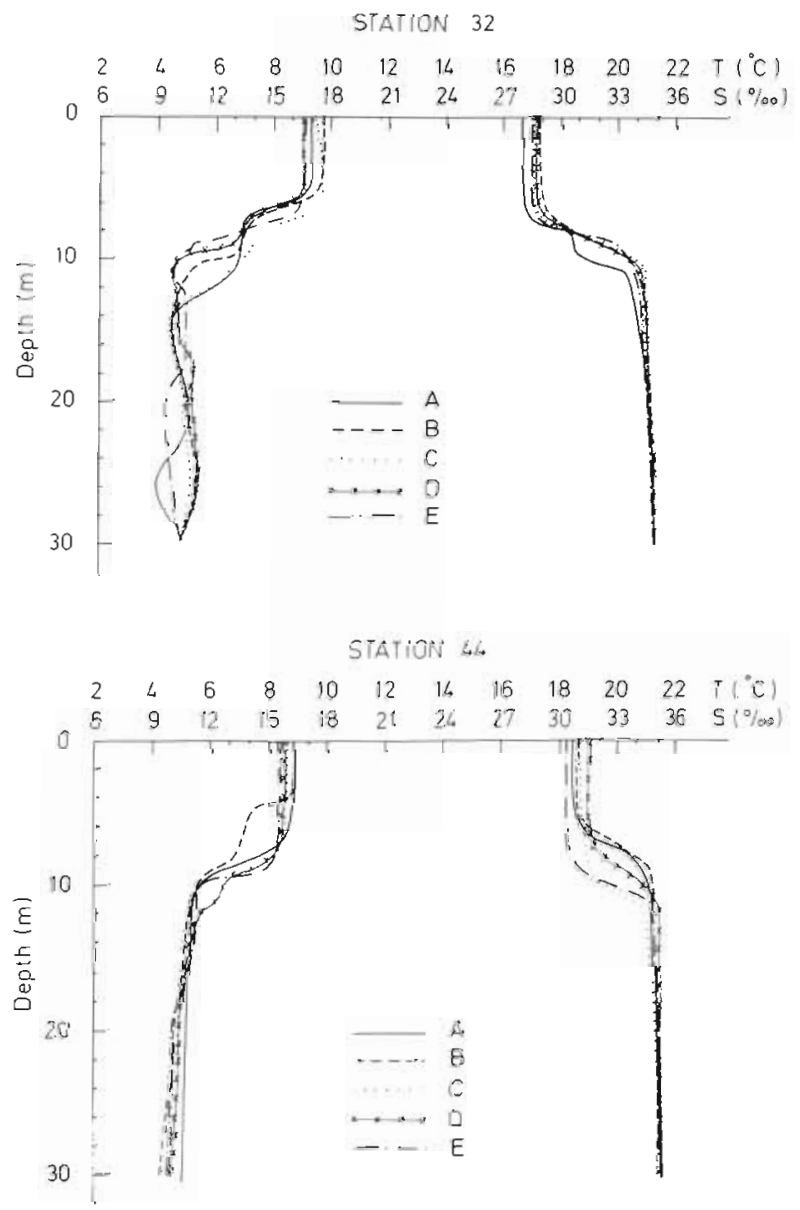

Fig. 2. Diel vertical temperature and salinity profiles at the diel Stns 13, 24, 32 and 44 during 12 to 21 May 1987 . Samples were taken at the following times: (A) 11:00 h; (B) 17:00 h; (C) $23: 00 \mathrm{~h}_{i}$ (D) 05:00 hi (E) 11:00 h 
45. The vertical distribution of $\mathrm{NO}_{3}{ }^{-}$and $\mathrm{PO}_{4}{ }^{3-}$ (Fig. 3) followed the general salinity-temperature profile pattern, i.e. with generally lower values above the pycnocline than below. At Stn 24, with the most homogeneous water body, vertical differentiation was least pronounced. The diel variation in salinity at Stn 13 was also reflected in the vertical nutrient distribution.

The concentration of $\mathrm{NO}_{3}{ }^{-}$at the surface decreased from between 1 and $3 \mu \mathrm{mol} \mathrm{I}^{-1}$ in the first week to $<1$ $\mu \mathrm{mol} \mathrm{I}^{-1}$ in the second week of the study. $\mathrm{PO}_{4}{ }^{3-}$ con- centrations were around $0.1 \mu \mathrm{mol} \mathrm{l}^{-1}$. Concentrations of silica at the surface were ca $1 \mu^{m o l ~} l^{-1}$ at Stns 13, 24 and 44 , and ca $0.5 \mu \mathrm{mol} \mathrm{l}^{-1}$ at Stn 32. In all measurements silica occurred in higher concentrations than phosphorus. Nutrient concentrations increased stepwise with increasing depth at Stns 32 and 44.

Concentrations of $\mathrm{NH}_{4}{ }^{+}$were generally lower than those of $\mathrm{NO}_{3}{ }^{-}$, but similar to $\mathrm{NO}_{3}{ }^{-}$in the above-pycnocline water at Stns $32 \mathrm{~A}$ to $\mathrm{C}$ and $44 \mathrm{~A}$ to $\mathrm{B}$ (Table 1). In many instances $\mathrm{NH}_{4}{ }^{+}$reached highest concentrations
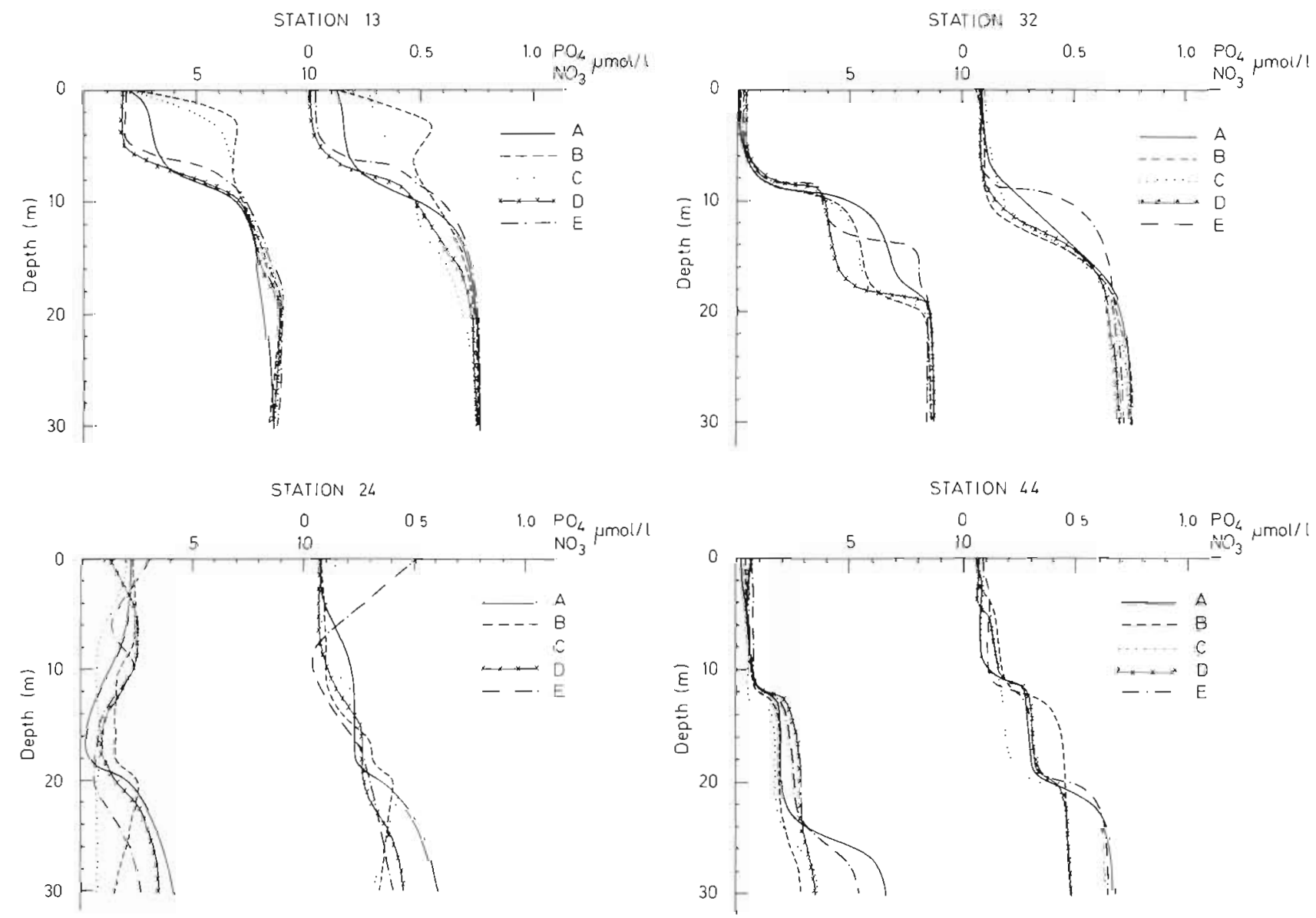

Fig. 3. Diel vertical distribution of $\mathrm{NO}_{3}{ }^{-}$(to the left in each figure) and $\mathrm{PO}_{4}{ }^{3-}$ at the 'diel' Stns $13,24,32$ and 44 . Further explanation in Fig. 2

Table 1. Diel recordings of ammonium ( $\left.\mu \mathrm{mol} \mathrm{l}^{-1}\right)$, above (A), in (I) and below (B) (always at $20 \mathrm{~m}$ depth) the pycnocline

\begin{tabular}{|c|c|c|c|c|c|c|c|c|c|c|c|c|}
\hline \multirow{3}{*}{$\begin{array}{l}\text { Time } \\
\text { (h) }\end{array}$} & \multicolumn{12}{|c|}{ Station and vertical position in relation to pycnocline } \\
\hline & \multicolumn{3}{|c|}{13} & \multicolumn{3}{|c|}{24} & \multicolumn{3}{|c|}{32} & \multicolumn{3}{|c|}{44} \\
\hline & A & 1 & $\mathrm{~B}$ & A & I & B & A & I & B & $\mathrm{A}$ & I & $\mathrm{B}$ \\
\hline $11: 00(\mathrm{~A})$ & 0.07 & 0.25 & 0 & - & - & - & 0.07 & 0.14 & 0.04 & 0.23 & 0.57 & 0.55 \\
\hline $17: 00(\mathrm{~B})$ & 0.11 & 0.20 & 0 & 0.18 & 0.05 & 0.27 & 0.17 & 0.27 & 0 & 0.23 & 0.28 & 0.54 \\
\hline $23: 00$ (C) & 0 & 0.22 & 0 & 0.72 & 0.30 & 0.17 & 0.07 & 0.18 & 0 & 0.03 & 0.13 & 0.32 \\
\hline 05:00 (D) & 0 & 0.18 & 0 & 0.05 & 0.20 & 0.34 & 0.02 & 0.12 & 0 & 0 & 0.04 & 0.22 \\
\hline $11: 00(\mathrm{E})$ & 0 & 0.08 & 0 & 0.29 & 0.24 & 0.39 & 0.09 & 0.07 & 0.02 & 0.10 & 0.06 & 0.24 \\
\hline
\end{tabular}


Table 2. Ambient concentration of particulate nitrogen (PN) and particulate carbon (PC), and the ratio of these (PC/PN), at the sampled depths above, in, and below the pycnocline. Values given for total particulate material and for the size fraction $<3 \mu m$. Average values for the diel studies expressed in $\mu \mathrm{mol} 1^{-1}$

\begin{tabular}{|c|c|c|c|c|c|c|c|}
\hline Station & Water mass & PN total & $\mathrm{PN}<3 \mu \mathrm{m}$ & PC total & $\mathrm{PC}<3 \mu \mathrm{m}$ & $\mathrm{PC} / \mathrm{PN}$ total & $\mathrm{PC} / \mathrm{PN}<3 \mu \mathrm{m}$ \\
\hline 13 & $\begin{array}{l}\text { Above } \\
\text { In } \\
\text { Below }\end{array}$ & $\begin{array}{l}2.1 \\
1.8 \\
1.5\end{array}$ & $\begin{array}{l}\text { nd } \\
\text { nd } \\
\text { nd }\end{array}$ & $\begin{array}{l}15.7 \\
14.6 \\
12.1\end{array}$ & $\begin{array}{l}\text { nd } \\
\text { nd } \\
\text { nd }\end{array}$ & $\begin{array}{l}7.6 \\
8.0 \\
8.1\end{array}$ & \\
\hline 24 & $\begin{array}{l}\text { Above } \\
\text { In } \\
\text { Below }\end{array}$ & $\begin{array}{l}2.8 \\
1.9 \\
1.4\end{array}$ & $\begin{array}{l}\text { nd } \\
\text { nd } \\
\text { nd }\end{array}$ & $\begin{array}{l}19.4 \\
13.3 \\
10.7\end{array}$ & $\begin{array}{l}\text { nd } \\
\text { nd } \\
\text { nd }\end{array}$ & $\begin{array}{l}6.9 \\
7.2 \\
7.7\end{array}$ & \\
\hline 32 & $\begin{array}{l}\text { Above } \\
\text { In } \\
\text { Below }\end{array}$ & $\begin{array}{l}5.5 \\
3.2 \\
1.0\end{array}$ & $\begin{array}{l}1.0 \\
\text { nd } \\
\text { nd }\end{array}$ & $\begin{array}{r}41.4 \\
21.0 \\
7.5\end{array}$ & $\begin{array}{l}7.3 \\
\text { nd } \\
\text { nd }\end{array}$ & $\begin{array}{l}7.5 \\
6.7 \\
7.3\end{array}$ & 7.7 \\
\hline 44 & $\begin{array}{l}\text { Above } \\
\text { In } \\
\text { Below }\end{array}$ & $\begin{array}{l}2.8 \\
2.3 \\
1.7\end{array}$ & $\begin{array}{l}1.1 \\
\text { nd } \\
\text { nd }\end{array}$ & $\begin{array}{l}18.2 \\
14.7 \\
11.2\end{array}$ & $\begin{array}{l}6.9 \\
\text { nd } \\
\text { nd }\end{array}$ & $\begin{array}{l}6.8 \\
6.4 \\
6.4\end{array}$ & 6.6 \\
\hline
\end{tabular}

in the halocline, corresponding to high abundance of flagellates. At Stns 13 and 32 low concentrations were recorded below the halocline, whereas higher levels were found at Stns 24 and 44. Urea concentrations did not show any increase with depth at Stn 44 , varying between 0.2 and $0.5 \mu \mathrm{mol} \mathrm{N} \mathrm{l}^{-1}$.

The distribution of phytoplankton was reflected in the steady decrease with depth of particulate nitrogen (PN) and particulate carbon (PC) concentrations at all 'diel' stations (Table 2). For example, at Stn 32 the average PN concentration in the surface water was 5.5 $\mu \mathrm{mol} \mathrm{I}^{-1}, 3.2 \mu \mathrm{mol} \mathrm{1^{-1 }}$ in the pycnocline and $1.0 \mu \mathrm{mol}^{-1}$ below the pycnocline. Size fractionation of water samples from above the pycnocline with $3 \mu \mathrm{m}$ filters revealed that ca $1 \mu \mathrm{mol} \mathrm{N}^{-1}$ and $7 \mu \mathrm{mol} \mathrm{C} \mathrm{l^{-1 }}$ were detected in particles $<3 \mu \mathrm{m}$ at Stns 32 and 44 . Total $\mathrm{PC} / \mathrm{PN}$ average ratios at the 'diel' stations ranged between 6.4 and 8.1 throughout the water column (Table 2). These values are in the range expected from the Redfield $\mathrm{C} / \mathrm{N}$ ratio of about 7.

\section{Phytoplankton}

The highest chl a estimates measured as in situ fluorescence at the 48 stations in the open Skagerrak were, with few exceptions, found in the upper $12 \mathrm{~m}$ and frequently associated with the pycnocline. They never exceeded $9 \mu \mathrm{g} \mathrm{l}^{-1}$, and were at most stations between 1 and $4 \mu \mathrm{g} \mathrm{l}^{-1}$. Among the 'diel' stations the highest chl a concentrations were measured at Stn 32 with peaks between 4.8 and $7.1 \mu \mathrm{g} \mathrm{l}^{-1}$

The phytoplankton was dominated by flagellates and monads, which were less than $3 \mu \mathrm{m}$ at all stations. They contributed 58 to $85 \%$ of total cell numbers and 16 to
$50 \%$ of biomass, expressed as phytoplankton carbon (Fig. 4). The total phytoplankton biomass was higher in the surface at Stns 24 and 32, mainly due to organisms in the size fraction 3-10 $\mathrm{m}$, which contained several small solitary Chaetoceros species.
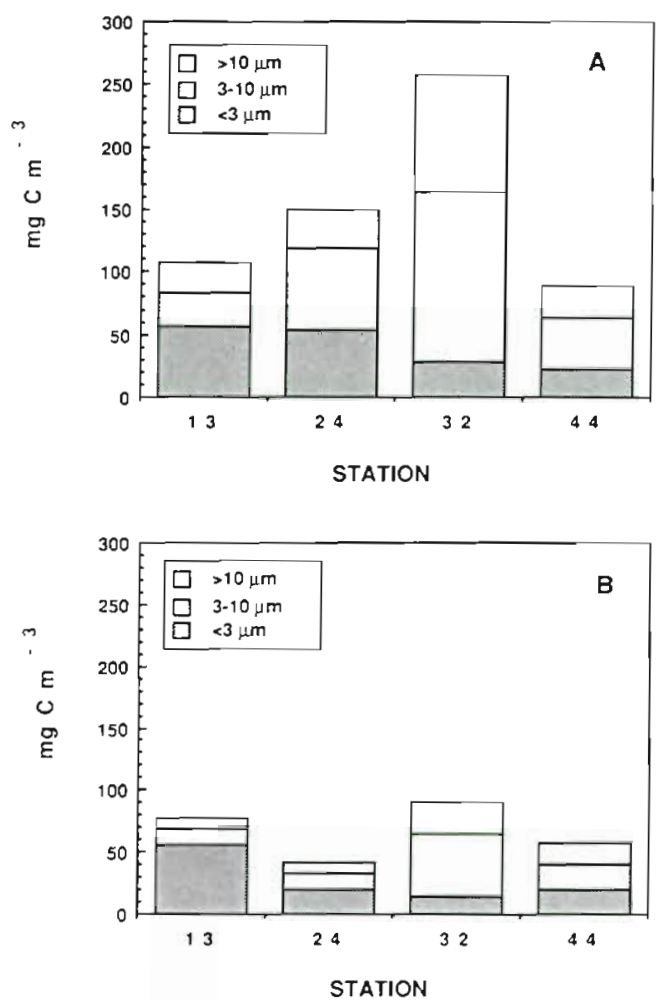

Fig. 4. Phytoplankton biomass $\left(\mathrm{mg} \mathrm{C} \mathrm{m} \mathrm{C}^{-3}\right.$ ) in different size fractions (A) above and (B) below the pycnocline at the 'diel' Stns $13,24,32$ and 44 
Among the 15 most abundant species little qualitative difference was noted between the stations. Second to flagellates and monads, small diatoms /Chaetoceros calcitrans, C. gracilis, C. perpusillus, C. wighamii, Nitzschia longissima), dinoflagellates (Gonyaulax excavata, G. triachantha, Gyrodinium fusiforme, Scrippsiella trochoidea and unidentified peridinians) and Calycomonas wulffi and Dinobryon balticum were common. Stns 24 and 32 had higher concentrations of diatoms and gave an impression of an earlier successional stage than Stns 13 and 44, where heterotrophic species were of greater relative importance.

The distribution of daily production showed a similar picture to that of chl $a$, with the highest rate at Stn 32 (888 $\mathrm{mg} \mathrm{C} \mathrm{m}^{-2} \mathrm{~d}^{-1}$ ) and the lowest at Stn 13 (160 mg C $\left.\mathrm{m}^{-2} \mathrm{~d}^{-1}\right)$. Stns 24 and 44 showed rates of 325 and 483 mg C m $\mathrm{m}^{-2} \mathrm{~d}^{-1}$ respectively (Table 3 ).

The productivity of different size fractions varied considerably from one station to another, but also within stations sampled at different times during $24 \mathrm{~h}$. At $\operatorname{Stn} 24$ and 32 productivity was mainly due to the $>10 \mu \mathrm{m}$ fraction, contributing 43 to $47 \%$ of total carbon uptake. The $<3$ and $3-10 \mu \mathrm{m}$ fractions each contributed 26 to $28 \%$ at both these stations.

At Stns 13 and 44 the $>10 \mu \mathrm{m}$ fraction was associated with 28 to $31 \%$ of the total carbon production. The $3-10$ $\mu \mathrm{m}$ fraction at $\operatorname{Stn} 13$ was responsible for $44 \%$ and the $<3 \mu \mathrm{m}$ fraction for $26 \%$ of the total carbon uptake. At Stn 44 these relations were reversed.

\section{Alkaline phosphatase activity (APA)}

APA showed relatively low values above the pycnocline. The mean value for samples from 0 to $7 \mathrm{~m}$ depth was $0.24 \mathrm{nM} \mathrm{P} \mathrm{min}{ }^{-1}$ (10 stations, range 0 to $1.1 \mathrm{nM} \mathrm{P}$ $\min ^{-1}$ ). Below the pycnocline APA was an order of magnitude lower, with a mean value of $0.02 \mathrm{nM} P$ $\min ^{-1}$ ( $\mathrm{n}=10$, range 0 to $0.16 \mathrm{nM} \mathrm{P} \mathrm{min}{ }^{-1}$ ). APA in surface waters showed a pronounced diel variation with a night-time minimum (Fig. 5).

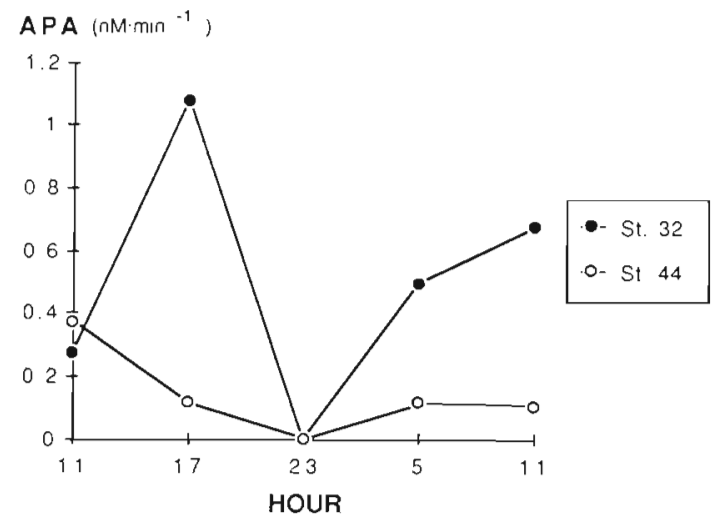

Fig. 5. Diel Alkaline Phosphatase Activity (APA; nM P min ${ }^{-1}$ ) at Stns 32 and 44

Nitrogen uptake rates

At Stn 32 the average daily uptake rate of nitrogen $\left(\mathrm{NH}_{4}{ }^{+}\right.$, urea and $\left.\mathrm{NO}_{3}{ }^{-}\right)$in the surface water was 1.13 , at the pycnocline 0.78 and below the pycnocline 0.21 umol $\mathrm{N} \mathrm{l}^{-1} \mathrm{~d}^{-1}$ (Fig. 6). The daily integrated uptake at

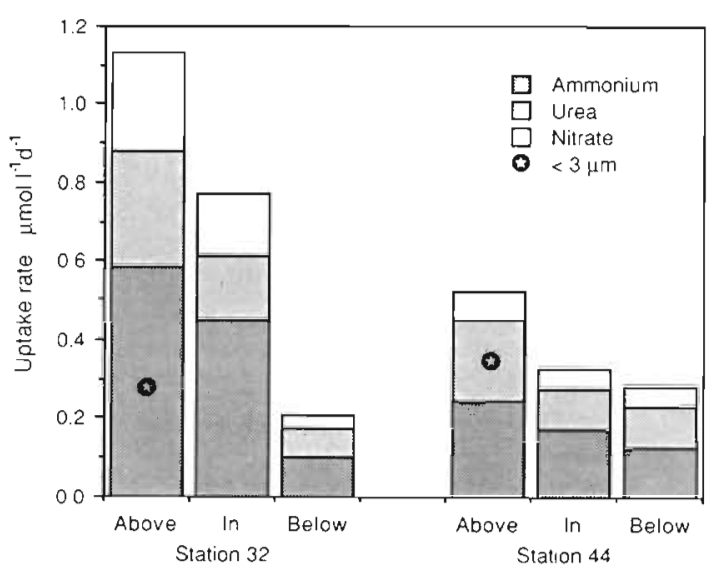

Fig. 6. Daily mean uptake rates of ammonium, urea and nitrate for total particulate material, and level of total uptake rate in the size fraction $<3 \mu \mathrm{m}$ at Stns 32 and 44 . The samples were taken above, in and below the pycnocline

Table 3. Losses of phytoplankton carbon from respiration, grazing and sedimentation, sum of losses and primary production in the depth range 0 to $20 \mathrm{~m}$ in the open Skagerrak. Unit: $\mathrm{mg} \mathrm{C} \mathrm{m} \mathrm{m}^{-2} \mathrm{~d}^{-1}$

\begin{tabular}{|c|c|c|c|c|c|c|}
\hline Station & Respiration & Grazing & Sedimentation & $\begin{array}{l}\text { Sum of } \\
\text { losses }\end{array}$ & $\begin{array}{l}\text { Primary } \\
\text { production }\end{array}$ & $\begin{array}{l}\text { Sedimentation as } \\
\text { percent of production }\end{array}$ \\
\hline 13 & 303 & 8 & $100^{\circ}$ & 411 & 160 & 63 \\
\hline 24 & 532 & 58 & 283 & 873 & 325 & 87 \\
\hline 32 & 508 & $60^{\mathrm{a}}$ & 151 & 719 & 888 & 17 \\
\hline 44 & $250^{a}$ & $10^{\mathrm{d}}$ & 101 & 361 & 483 & 21 \\
\hline \multicolumn{7}{|c|}{ "Calculated values } \\
\hline
\end{tabular}


Stn $32(0$ to $20 \mathrm{~m})$ was $12.74 \mathrm{mmol} \mathrm{N} \mathrm{m}^{-2} \mathrm{~d}^{-1}$. $\mathrm{NH}_{4}^{+}$ uptake rates accounted on average for $52 \%$, urea for $28 \%$ and $\mathrm{NO}_{3}-$ for $20 \%$ of total nitrogen uptake. The size fraction $<3 \mu \mathrm{m}$ accounted for on average $25 \%$ of total nitrogen uptake in the surface water. There was no clear depression in uptake rates at night.

At $\operatorname{Stn} 44$ average total nitrogen uptake rate in the surface water was $0.53 \mu \mathrm{mol}$, at the pycnocline 0.33 $\mu \mathrm{mol}$ and in the deep water $0.28 \mu \mathrm{mol} \mathrm{N} \mathrm{l}^{-1} \mathrm{~d}^{-1}$. Daily integrated uptake rate at Stn 44 (0 to $20 \mathrm{~m}$ ) was 7.50 mmol $\mathrm{N} \mathrm{m}^{-2} \mathrm{~d}^{-1}$. Ammonium uptake constituted on average $47 \%$, urea uptake $37 \%$ and nitrate uptake $16 \%$ of total nitrogen uptake. Picoplankton $(<3 \mu \mathrm{m})$ accounted for an average $63 \%$ of total nitrogen uptake. There was no decrease in uptake rate during the night.

\section{Microbial food web}

Each 'diel' station and each sample taken above, in and below the pycnocline was compared. Bacterial production showed a systematic diel variation $(p<$ 0.03 , 2-way ANOVA), with higher values during day light (Fig. 7). A systematic dependence could not be seen when comparing production rates above, in and below the pycnocline. However, bacterial growth tended to be lower below the pycnocline with an average value of $1.6 \times 10^{5}(\mathrm{SE}=0.53, \mathrm{n}=3)$ cells $\mathrm{ml}^{-1} \mathrm{~d}^{-1}$. compared to $2.5 \times 10^{5}(\mathrm{SE}=0.73, \mathrm{n}=3)$ cells $\mathrm{ml}^{-1} \mathrm{~d}^{-1}$ above the pycnocline.

Predation on bacteria also showed a systematic diel variation ( $p<0.001,2$-way ANOVA), with higher predation rates during daytime (Fig. 7). The diel response varied in strength between the experiments without any significant correlation to site and water body sampled. For all parameters measured the weakest dynamics were found at the deepest sampling point (below pycnocline at $18 \mathrm{~m}, \mathrm{Stn} 24$ ). Highest integrated rates of predation were observed above the pycnocline (Stns 13 and 24). Com- paring Stns 13 and 24, predation on bacteria and bacterial production were both higher at the latter.

Contrary to bacterial growth and predation on bacteria, bacterial numbers varied between 0.7 and $3.6 \times$ $10^{6}$ cells $\mathrm{ml}^{-1}$ without any systematic dependence on time of day (Fig. 7). Changes in numbers equal to the standing stock of bacteria could be found within $6 \mathrm{~h}$. On average, the bacterial population was regularly found to be most dense in the pycnocline $(p<0.02,2$-way ANOVA) (Fig. 8). Flagellate numbers were also found to be systematically higher in the pycnocline than below ( $\mathrm{p}$ $<0.05$, t-test) (Fig. 8). In individual experiments flagellate numbers showed pronounced variation within $6 \mathrm{~h}$. However, as for bacteria, flagellate numbers lacked a systematic dependence on time of day.

In absolute terms, predation on bacteria was found to exceed bacterial production. For example at Stn 13 above the pycnocline, predation rate was $19.5 \times 10^{5}$ cells $\mathrm{ml}^{-1} \mathrm{~h}^{-1}$ while the simultaneous bacterial production rate was $1.1 \times 10^{5}$ cells $\mathrm{ml}^{-1} \mathrm{~h}^{-1}$. On average, the predation estimate proved to exceed the bacterial production estimate by a factor $8.4(\mathrm{SD}=5.6, \mathrm{~N}=8)$. Since this relationship most likely results from methodological errors, a comparison was made between an increase in bacterial cell numbers and integrated bacterial production (tritiated thymidine incorporation, TTI). Average minimum growth of the bacteria, calculated during increases in bacterial numbers, was estimated at $13.3 \times$ $10^{4}$ cells $\mathrm{ml}^{-1} \mathrm{~h}^{-1}$. This should be compared with the integrated bacterial production during the same time period (TTI), which amounted to $1.2 \times 10^{4}$ cells $\mathrm{ml}^{-1} \mathrm{~h}^{-1}$.

Bacterial carbon production can be estimated as follows. Assuming $0.22 \mathrm{pg} \mathrm{C} \mu \mathrm{m}^{-3}$ (Bratbak \& Dundas 1984) and an average bacterial volume of $0.06 \mu \mathrm{m}^{3}$ (e.g. Lee \& Fuhrman 1987), 160 and $356 \mathrm{mg} \mathrm{C} \mathrm{m}^{-2} \mathrm{~d}^{-1}$ would have been produced at Stns 13 and 24, respectively.

It is assumed that the majority of the bacteria produced are consumed by flagellates (ca $25 \mu \mathrm{m}$ ) as indicated by size fractionation experiments (data not

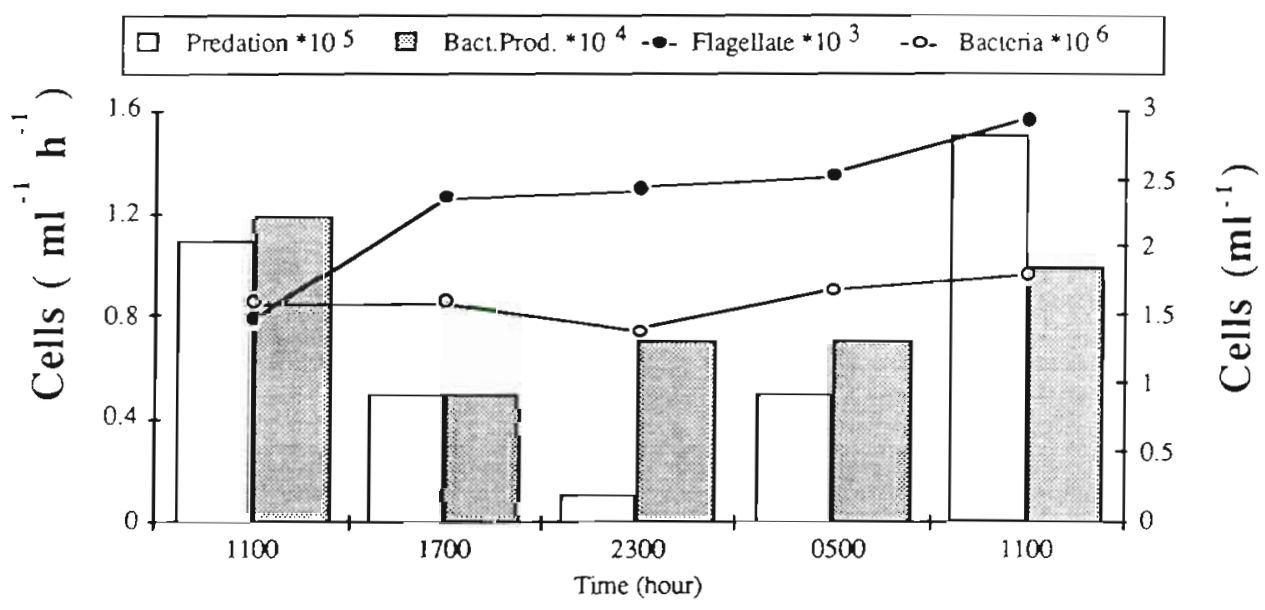

Fig. 7 Temporal dependence of microbial activities and cell numbers. Predation on and growth of heterotrophic bacteria showed systematic diel variations $(p<0.001$ and $<0.03$, respectively; 2 -way ANOVA] 
shown). This has also been shown in other waters (Wikner \& Hagström 1988).

The growth need of flagellates feeding on bacterioplankton can be calculated assuming a growth rate of 1 per day, a carbon content of $4.8 \mathrm{pg} \mathrm{C}$ flagellate ${ }^{-1}, 44 \%$ growth efficiency for the flagellate, and a carbon content of $13.2 \times 10^{-15} \mathrm{~g} \mathrm{C}$ bacteria $^{-1}$ (Fenchel 1982a, Bratbak \& Dundas 1984, Caron et al. 1985, Lee \& Fuhrman 1987). The calculated flagellate growth need was 35 bacterial cells flagellate ${ }^{-1} h^{-1}$, in accordance with the ingestion rates of cultured flagellates, which have been shown to be in the order of 10 to 340 bacterial cells flagellate ${ }^{-1} \mathrm{~h}^{-1}$ (Davis \& Sieburth 1984). Comparison can now be made between the estimated flagellate assimilation (flagellate numbers times growth needs) of 180 and $246 \mathrm{mg} \mathrm{C} \mathrm{m}^{-2} \mathrm{~d}^{-1}$ for Stn 13 and 24 respectively, and the measured grazing of bacteria of 160 and $356 \mathrm{mg} \mathrm{C} \mathrm{m} \mathrm{m}^{-2}$. This comparison encouraged us to base our estimate of bacteria assimilation on the measured grazing on bacteria. Thus, using an assimilation factor of 0.6 (Payne 1970, Button 1985) for heterotrophic bacteria, the bacterial growth demand exceeded the net incorporation of ${ }^{14} \mathrm{C}$ into particulate matter (primary production) at both Stns 13 and 24 (see Table 8). It is clear, however, that the apparently high respiration and $\mathrm{CO}_{2}$ consumption measured in the water column can partly be met through the respiration of bacteria and flagellates.

\section{Zooplankton}

Zooplankton biomass above the pycnocline was highest during the night due to the upward migration of copepods (Table 4). Biomasses during the day were 0.3 and about $10 \mathrm{mg} \mathrm{C} \mathrm{m}^{-3}$ at Stns 13 and 24 , respectively, whereas corresponding night biomasses were $30.7 \mathrm{mg} \mathrm{C} \mathrm{m}{ }^{-3}$ and $67.3 \mathrm{mg} \mathrm{C} \mathrm{m}^{-3}$. Calanus finmarchicus dominated the zooplankton biomass at both stations except for the night sample at Stn 13, where the camivorous Paraeuchaeta norvegica was the most abundant copepod. Species composition is described in detail in Tiselius (1988).

Copepod grazing rate followed the same diel pattern

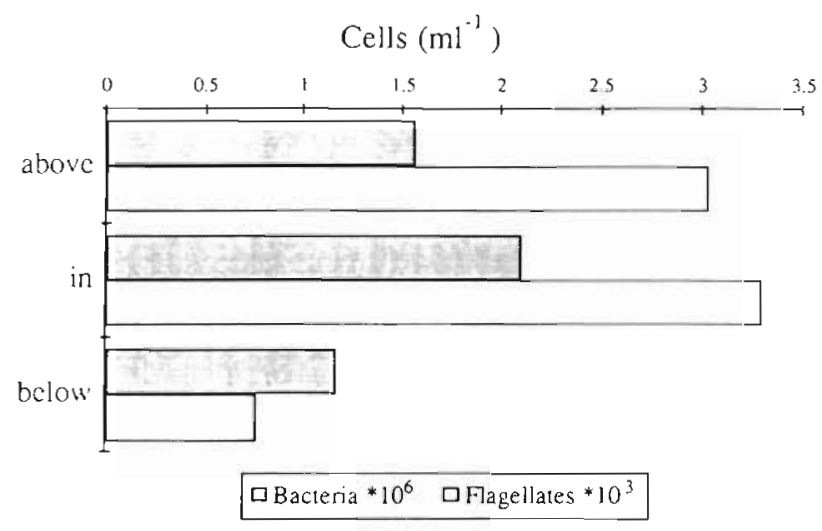

Fig. 8. Bacterial and flagellate numbers in relation to the pycnocline. Bacterial numbers were statistically different from each other $(p<0.02,2$-way ANOVA), while flagellate numbers were higher in the pycnocline than below ( $p<0.05$, t-test)

as biomass, since Calanus finmarchicus was the dominant grazer (Table 4). A more than 10-fold difference was observed between day and night, from 0.02 to 0.4 $\mu \mathrm{g}$ pigment $\mathrm{m}^{-3} \mathrm{~h}^{-1}$ at Sth 13 and from 0.3 to $4.6 \mu \mathrm{g}$ pigment $\mathrm{m}^{-3} \mathrm{~h}^{-1}$ at $\mathrm{Stn} 24$ (Table 4). The weightspecific grazing rate of $C$. finmarchicus was similar at Stns 13 and $24,0.019$ to 0.057 and 0.016 to $0.065 \mathrm{ng}$ pigment $\mu \mathrm{gC}^{-1} \mathrm{~h}^{-1}$, respectively, whereas egg production was higher at $\operatorname{Stn} 24\left(18.9 \pm 6.3\right.$ eggs female $\left.\mathrm{d}^{-1}\right)$ than at $\operatorname{Stn} 13\left(9.8 \pm 2.5\right.$ eggs female $\left.{ }^{-1} d^{-1}\right)$.

\section{Sedimentation and oxygen consumption}

Sedimentation rates were lowest for Stn 44 (and also estimated low for Stn 13) and highest for Stn 24 (Table 3). The sedimenting material at Stns 24,32 and 44 had high $\mathrm{C} / \mathrm{N}$ molar ratios and $\mathrm{C} / \mathrm{Chl}$ a weight ratios of 10 to 13 and 114 to 149 , respectively. The same mean ratios of the phytoplankton above the halocline were 7.5 and 82 respectively. About $20 \%$ of the newly produced carbon was lost by sedimentation at Stns 32 and 44 , whereas it was $87 \%$ at Stn 24 (Table 3). Primary production at this station was low partly due to low light intensity and partly due to low activity of the phytoplankton, indicated by low potential production.

Table 4. Biomass and grazing rates of zooplankton at Stns 13 and 24. Weights are based on length-weight regressions referred in Tiselius (1988)

\begin{tabular}{|c|c|c|c|c|c|c|c|c|c|}
\hline & \multicolumn{4}{|c|}{$\operatorname{Stn} 13$} & \multicolumn{5}{|c|}{ Stn 24} \\
\hline & \multirow{2}{*}{$\begin{array}{l}\text { Depth } \\
(\mathrm{m})\end{array}$} & \multicolumn{3}{|c|}{ Time (h) } & \multirow{2}{*}{$\begin{array}{l}\text { Depth } \\
(\mathrm{m})\end{array}$} & \multicolumn{4}{|c|}{ Time $(\mathrm{h})$} \\
\hline & & $15: 00$ & $20: 00$ & $01: 00$ & & $17: 00$ & $23: 00$ & $05: 00$ & $11: 00$ \\
\hline \multirow[t]{2}{*}{ Biomass ( $\mathrm{mgC} \mathrm{m} \mathrm{m}^{-3}$ ) } & $0-15$ & 0.3 & 0.5 & 30.7 & $0-10$ & 10.5 & 67.3 & 29.0 & 10.1 \\
\hline & & & & & $10-30$ & 52.8 & 14.3 & 31.5 & 14.9 \\
\hline \multirow{2}{*}{$\begin{array}{l}\text { Grazing ( } \mu \text { g chl a } \\
\text { equivalents } \mathrm{m}^{-3} \mathrm{~h}^{-1} \text { ) }\end{array}$} & 5 & 0.02 & 0.02 & 0.4 & 5 & 0.3 & 4.6 & 1.9 & 0.3 \\
\hline & 12 & 0.02 & 0.02 & 0.5 & 12 & 1.2 & 1.0 & 2.2 & 0.4 \\
\hline
\end{tabular}


Planktonic respiration, measured as oxygen consumption, was determined at Stns 13,24 and 32 (Table 3). Oxygen values were transformed to carbon using the stoichometric ratio and by assuming a $R Q$ of 0.85 (Wassmann 1984). Integrated values covering the surface to $20 \mathrm{~m}$ depth were considerably higher at Stns 24 and 32 (532 and $508 \mathrm{mg} \mathrm{C} \mathrm{m}^{-2} \mathrm{~d}^{-1}$, respectively) than at Stn 13 (303 $\mathrm{mg} \mathrm{C} \mathrm{m}^{-2} \mathrm{~d}^{-1}$ ). The respiration at Stn 13 was about $190 \%$ of the phytoplankton production, calculated for the $24 \mathrm{~h}$ period. At Stn 24, too, the respiration exceeded the production $(135 \%)$, whereas at Stn $32,60 \%$ of the carbon production was respired.

Below the pycnocline respiration was $<1 \mathrm{ml} \mathrm{O}_{2} \mathrm{~m}^{-3}$ $\mathrm{h}^{-1}$ with a tendency towards lower values in deeper waters (Fig. 9). The mean for all measurements below the halocline was $0.36 \mathrm{ml} \mathrm{O}_{2} \mathrm{~m}^{-3} \mathrm{~h}^{-1}$ or $0.16 \mathrm{mg} \mathrm{C} \mathrm{m}^{-3}$ $\mathrm{h}^{-1}$ if $\mathrm{RQ}=0.85(\mathrm{n}=16, \mathrm{SD}=0.17)$. The number of measurements was too low to permit comparisons between different stations.

\section{Sediments and benthic fauna}

The percentage fines of the sediments and ignition loss increased with depth at Stns 24,32 and 44 (Table 5). Stn 24 was mainly sandy, Stn 32 contained sand-siltclay in about equal proportions, and Stn 44 was silty clay. Thus, accumulation of organic material increased with depth which might mirror higher long-term sedimentation rates at deeper stations.

Investigation of the benthic fauna showed that number of species, abundance and biomass were higher at Stns 24 and 32 than at Stn 44 (Table 5). Diversity was highest at Stn 44. Dominants at Stn 24 were the brittle star Amphiura filiformis (423 ind. $\mathrm{m}^{-2}$ ) and the polychaetes Myriochele sp. (357) and Rhodine gracilor (253). Dominant at Stn 32 was the bivalve Abra alba (797) and at Stn 44 the bivalve Thyasira equalis $\left(177\right.$ ind. $\left.\mathrm{m}^{-2}\right)$. A. filiformis is a suspension feeder and the other 4 dominants are deposit feeders. The high

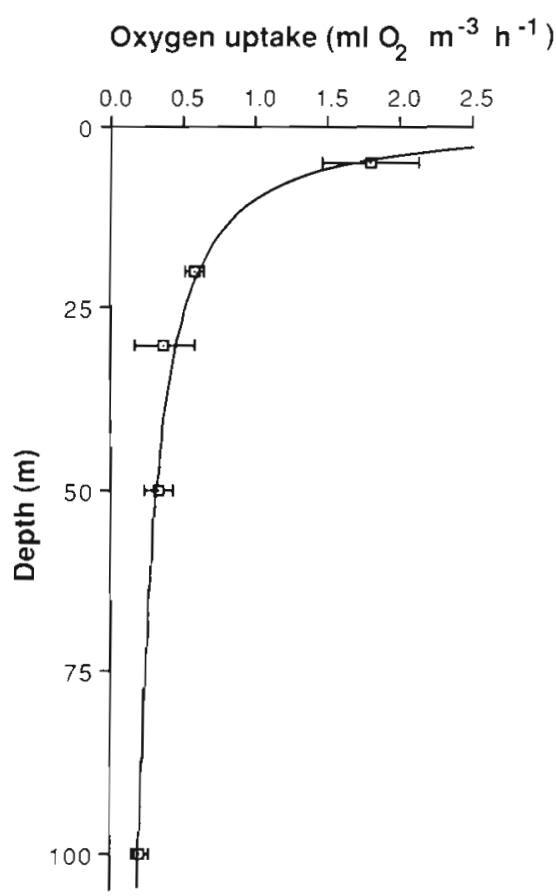

$\log \mathrm{mlO}_{2} \mathrm{~m}^{-3} \mathrm{~h}^{-1}=0.73-0.73 \log$ depth $r^{2}=0.98$

Fig. 9. Respiration (mean and standard deviation) in relation to depth. Pooled values from Stns 13, 24, 32 and 44

biomass at Stn 24 was partly due to one specimen of the bivalve Arctica islandica contributing $322 \mathrm{~g} \mathrm{~m}^{-2}$.

\section{Skagerrak coast}

Hydrography and nutrients

The surface water of Gullmarsfjord was dominated by water of Baltic origin. The salinity at $0.5 \mathrm{~m}$ depth during the period of investigation was 24 to $26 \%$,

Table 5. Number of benthic macrofaunal species per $0.3 \mathrm{~m}^{2}$, abundance $\mathrm{m}^{-2}$, biomass in $\mathrm{g} \mathrm{m}^{-2}$ (wet weight), diversity $\mathrm{H}^{\prime}$, and evenness $\mathrm{J}$ and sediment characteristics at 3 stations in the open Skagerrak

\begin{tabular}{|lccc|}
\hline Parameter & & Stations and depths & 44 \\
& 24 & $(240 \mathrm{~m})$ & $(\mathrm{m})$ \\
\hline Number of species & $(108 \mathrm{~m})$ & 61 & 35 \\
Abundance & 73 & 2577 & 683 \\
Biomass & 2297 & 78 & 40 \\
Diversity H' & 591 & 3.6 & 4.1 \\
Evenness J' & 4.0 & 0.61 & 0.80 \\
Ignition loss (\%) & 0.64 & 6.6 & 10.3 \\
Sediment, percentage fines $(<50 \mu \mathrm{m})$ & 13 & 65 & 98 \\
\hline
\end{tabular}


except on 15 May when it was $28.4 \%$. The halocline was situated from ca $5 \mathrm{~m}$ (11 to $15 \mathrm{May}$ ) to $15 \mathrm{~m}$ (18 to 22 May). The surface temperature ranged between 7 and $9{ }^{\circ} \mathrm{C}$. Below the pycnocline colder $\left(3\right.$ to $\left.4^{\circ} \mathrm{C}\right)$ water with a salinity of 32 to $33 \%$ was present. Below $60 \mathrm{~m}$ was stagnant water with a temperature of 4.8 to $5.3^{\circ} \mathrm{C}$ and a salinity of $34.7 \%$. The oxygen concentration in the stagnant water $(60$ to $120 \mathrm{~m}$ ) varied between 4.6 and $3.9 \mathrm{ml} \mathrm{l}^{-1}$ and the oxygen consumption rate was estimated to $0.83 \mathrm{ml} \mathrm{m}^{-3} \mathrm{~h}^{-1}$.

The nutrient concentrations of the different water bodies within the water column of the fjord are given in Table 6 . The concentration of $\mathrm{NO}_{3}{ }^{-}$increased with depth, while the maximum concentration of $\mathrm{NH}_{4}{ }^{+}$was found in the intermediate water layer. The concentration of $\mathrm{PO}_{4}{ }^{3-}$ also increased with depth while the concentration of TP was lowest in the depth range 15 to $45 \mathrm{~m}$.

\section{Phytoplankton}

Chl a was measured on 15, 19 and 21 May and concentrations varied between 2.8 and $9.8 \mu \mathrm{g} \mathrm{l}^{-1}$ down to $15 \mathrm{~m}$ depth, and were in the range 0.6 to $2.0 \mu \mathrm{g} \mathrm{l}^{-1}$ further down to $30 \mathrm{~m}$ depth. Integrated over depth $(30 \mathrm{~m})$ the concentrations were 68,207 and $60 \mathrm{mg} \mathrm{m}^{-2}$ on 15, 19 and 21 May, respectively.

On 19 May phytoplankton (excluding sizes $<10 \mu \mathrm{m}$ ) was dominated by dinoflagellates, mainly Gonyaulax excavata and Dinophysis norvegica, from surface to $20 \mathrm{~m}$ depth. Abundance ranged from 11300 to 360 cells $1^{-1}$ for $G$. excavata and from 7720 to $440{\text { cells } l^{-1}}^{-1}$ for $D$. norvegica at different depth intervals.

Primary production on 15 May was in the range 7 to 12

Table 6. Mean concentrations of $\mathrm{NO}_{3}{ }^{-}, \mathrm{NH}_{4}{ }^{+}, \mathrm{PO}_{4}{ }^{3-}$ and total phosphorus (TP; $u$ mol $1^{-1}$ ) in the different water layers of Gullmarsfjord on 19 May 1987

\begin{tabular}{|lcccc|}
\hline Water layer & $\mathrm{NO}_{3}{ }^{-}$ & $\mathrm{NH}_{4}{ }^{+}$ & $\mathrm{PO}_{4}{ }^{3-}$ & $\mathrm{TP}$ \\
\hline Above pycnocline $(0-15 \mathrm{~m})$ & 0.61 & 0.27 & 0.23 & 1.17 \\
In and below pycnocline & & & & \\
$\quad(15-45 \mathrm{~m})$ & 4.08 & 0.54 & 0.37 & 0.76 \\
Stagnant water $(60-120 \mathrm{~m})$ & 7.52 & $\sim 0$ & 1.22 & 1.53 \\
\hline
\end{tabular}

mg $\mathrm{C} \mathrm{m}^{-3} \mathrm{~h}^{-1}$ down to $8 \mathrm{~m}$ depth. It was small or negligible deeper down. Integrated over depth the primary production was calculated to $83 \mathrm{mg} \mathrm{C} \mathrm{m}^{-2} \mathrm{~h}^{-1}$ corresponding to $882 \mathrm{mg} \mathrm{C} \mathrm{m}{ }^{-2} \mathrm{~d}^{-1}$

The production profile over depth had changed on 20 May. Maximum production ( 25 to $30 \mathrm{mg} \mathrm{C} \mathrm{m}^{-3} \mathrm{~h}^{-1}$ ) was now found from the surface down to $2 \mathrm{~m}$ depth. Production decreased rapidly below this depth and was negligible below $8 \mathrm{~m}$. Integrated over depth the production was calculated to $113 \mathrm{mg} \mathrm{C} \mathrm{m}^{-2} \mathrm{~h}^{-1}$ (or $1112 \mathrm{mg} \mathrm{C} \mathrm{m}^{-2}$ $\left.d^{-1}\right)$.

\section{Sedimentation}

Between 21 and 25 May the sedimentation of total particulate material (TPM) increased over depth (Table 7 ), indicating that resuspension occurred. This effect is also indicated by the decreasing ratio over depth between particulate organic matter (POM) and TPM. The mean daily primary production of 15 and 20 May and the sedimentation of $\mathrm{PC}$ at $20 \mathrm{~m}$ gave a ratio of 0.52 indicating that new production then was about $50 \%$ of total production, if steady-state is assumed.

The oxygen consumption of $0.83 \mathrm{ml} \mathrm{m}^{-3} \mathrm{~h}^{-1}$ equals a carbon consumption of about $0.39 \mathrm{mg} \mathrm{m}^{-3} \mathrm{~h}^{-1}$ ( $\mathrm{RQ}=$ $0.85)$. When integrated over $25 \mathrm{~m}$ depth in the deep water (using the mean depth of $85 \mathrm{~m}$ below the $60 \mathrm{~m}$ depth) the daily carbon consumption was estimated to $230 \mathrm{mg} \mathrm{C} \mathrm{m}^{-2}$ $d^{-1}$, i.e half of the measured sedimentation rate.

\section{DISCUSSION}

\section{Pycnocline, nutrients and chlorophyll}

During this May cruise all 48 stations in the open Skagerrak had a pycnocline close to the surface. At the 4 'diel' stations the pycnocline lay between 5 and $12 \mathrm{~m}$ depth. Nutrient concentrations were in general much lower above the pycnocline than below, whereas chl a was highest in the pycnocline. However, temporal and horizontal differences in the open Skagerrak were apparent during the $2 \mathrm{wk}$ of study. The diel investigations at Stns 13 and 24 during the first week showed short-term pronounced vertical movements of the

Table 7 Sedimentation of total particulate material (TPM), particulate organic material (POM), particulate carbon (PC) and particulate nitrogen (PN) in $\mathrm{mg} \mathrm{m} \mathrm{m}^{-2} \mathrm{~d}^{-1}$ between 21 and 25 May 1987 at 20, 40, 60 and $110 \mathrm{~m}$ depth in Gullmarsfjord

\begin{tabular}{|ccccccc|}
\hline Depth $(\mathrm{m})$ & TPM & POM & POM/TPM (\%) & PC & PN & PC/PN (\%) \\
\hline 20 & 3280 & 1340 & 41 & 520 & 50 & 10 \\
40 & 3850 & 1060 & 28 & 500 & 50 & 9 \\
60 & 4440 & 1120 & 25 & 480 & 50 & 9 \\
110 & 5900 & 1320 & 22 & 490 & 50 & 9 \\
\hline
\end{tabular}


pycnocline and, in association with this, short-term vertical variations in nutrient concentrations. The low surface salinity at $\operatorname{Stn} 13$ reflects the influence of brackish water of mainly Baltic origin.

In earlier investigations in the open Skagerrak in April 1984 (Richardson 1985) and in August 1981 (Pingree et al. 1982), the chl a concentrations were generally $<5 \mu \mathrm{g} \mathrm{l}^{-1}$. They were, however, elevated in fronts associated to weakenings of the halocline (Richardson 1985), or in relation to doming of the thermocline in late summer (Pingree et al. 1982). In the present study no such clear elevations were noted either in the open Skagerrak or in Gullmarsfjord.

In Gullmarsfjord the above-pycnocline salinity was lower than in the open Skagerrak, whereas the vertical distribution of temperature was similar. The vertical position of the pycnocline in Gullmarsfjord was, as in the Skagerrak, variable between 5 and $15 \mathrm{~m}$.

\section{Nutrients}

Mean diel IN/IP (inorganic nitrogen/inorganic phosphorus) molar ratios in the surface water at Stns 13, 24 , 32 and 44 in the open Skagerrak were 15.0, 25.2, 4.0 and 9.7 , respectively. Similarly, the ratios at $30 \mathrm{~m}$ were $11.2,74.0,11.8$ and 9.0. In comparison with the Redfield ratio of 16 , it seems that nitrogen was in relative deficit for phytoplankton growth at Stns 32 and 44 in the surface water and also that the ratios in most cases were low at $30 \mathrm{~m}$. As Stns 32 and 44 were sampled during the second week of the cruise the results suggest that relatively more nitrogen had been taken up by phytoplankton than phosphorus, or that the water from the first week had been replaced by less nitrogenrich water. Urea was analysed the second cruise week only, but there is no reason to belive that urea should alter the above-mentioned ratios significantly between the samplings. The finding, however, that most of the nitrogen uptake was as $\mathrm{NH}_{4}{ }^{+}$and urea shows that regeneration of nitrogenous nutrients was important for primary production.

As measurable levels of APA were found in a few samples during the second week at least some algal size classes may have been phosphorus-deficient. However, high APA is not always a sign of phosphorus deficiency, as bacteria, phytoplankton and zooplankton can produce alkaline phosphatases in the presence of high concentrations of inorganic phosphorus (Jansson 1976, Stevens \& Parr 1977, Wynne 1981). Our measurements do not indicate any pronounced general phosphate deficiency, which is in accordance with APA measurements made in the Kattegat by Nyman \& Granéli (1983), but contrary to what has been found in the North Sea (Veldhuis et al.
1987). Even if APA was generally low there were consistent diel variations with zero night-time values. This may either indicate that APA is only connected to photosynthesis or phagotrophic processes, or that during night there was an excess of available phosphate repressing the enzyme. This could for example, be due to increased zooplankton excretion in surface waters at night, when animals migrate upwards as was shown in this and other studies (Porter 1976, Bergquist \& Carpenter 1986).

In Gullmarsfjord nutrients were analyzed on 19 May only. The vertical distribution of $\mathrm{NO}_{3}{ }^{-}$in relation to the pycnocline was then similar to that at Stns 32 and 44 during the same week. The corresponding $\mathrm{PO}_{4}{ }^{3-}$ concentrations were, however, higher above and below the pycnocline in Gullmarsfjord. The IN/IP ratio (from Table 6 ) of 3.8 above the pycnocline suggests that phosphorus was in relative excess to nitrogen in samples for primary production in that water body.

In the open Skagerrak the PC/PN molar ratios were fairly constant $(6.4$ to 8.1$)$ in water samples at the 4 'diel' stations from the surface to below the pycnocline (Table 2). In sedimenting material at 20 to $40 \mathrm{~m}$ higher ratios of 10.1 to 12.1 were analyzed at Stns 24 and 32 (Table 7 ), indicating a more rapid mineralization of nitrogen compared to carbon during sedimentation (cf Blackburn \& Henriksen 1983). In Gullmarsfjord the corresponding ratios were between 9 and 10 (20 to $110 \mathrm{~m}$ depth).

Nutrients were available in excess just below the pycnocline, of which the depth reached $12 \mathrm{~m}$ in the open Skagerrak but was generally shallower. Thus, nutrients could limit primary production in the shortterm, but nutrients could be supplied from the reservoir below the pycnocline, e.g. by vertical migration of algae, and/or by the diel migration of zooplankton and by their nutrient supply through excretion and sloppy feeding. The importance of zooplankton for the regeneration of nitrogen has been shown from southern North Sea stratified waters (Holligan et al. 1984).

\section{Plankton, including bacteria}

In the open Skagerrak small $(<3$ um) flagellates and monads dominated the phytoplankton numerically at all stations. At Stn 13 even the biomass was dominated by small algal cells. The relative importance of primary production in different size groups varied between stations. At Stn 32 the picoplankton $(<3 \mu \mathrm{m})$ contributed about $25 \%$ of the total primary production and similarly $25 \%$ of the total nitrogen uptake. At Stn 44 picoplankton contributed $63 \%$ of the total primary production and $44 \%$ of total nitrogen 
uptake. At the other 2 stations $(13,24)$ the picoplankton, as at Stn 32 , made up $<30 \%$ of the primary production. Thus, it seems that picoplankters were relatively more important as producers and for nitrogen cycling at Stn 44 than at the others. Larger size groups were relatively more important at the other stations. No size-fractioned analysis was made at the station in Gullmarsfjord.

Bacterial growth seemed in general terms to be higher at midday than during the night (Fig. 7). Diel variation in bacterial growth has been observed by several authors (Sieburth et al. 1977, Riemann \& Söndergaard 1984, Hagström \& Larsson 1984, Fuhrman et al. 1985) in enclosed water samples, which minimize patchiness as a source of variation. In the open Skagerrak, patchiness certainly influenced the estimates of both bacterial production and grazing. However, this did not overshadow the variation due to diel fluctuations of other origin, according to the 2way ANOVA ( $p<0.001)$. Therefore, a diel rhythm in bacterial growth and bacterivory was indeed present.

Grazing on bacteria showed a similar diel pattern to bacterial production (Fig. 7), Variations in predation on bacteria with time of day have previously been reported (Wikner et al. 1990) in enclosed water samples. The highest absolute rates of predation were observed above the pycnocline during daytime, and a similar diel pattern of predation was observed both in and below the pycnocline.

The apparent discrepancy between the integrated bacterial production and predation on bacteria is discussed in Wikner et al. (1990) and was suggested to be mainly due to a variation in the conversion factor from moles of thymidine incorporated to cells produced. A

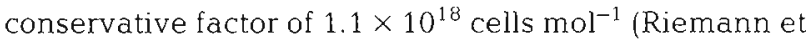
al. 1987) was used here, while recent reports have demonstrated that actual conversion factors may vary between 1.1 and $38 \times 10^{18}$ cells mol $^{-1}$ (Coveney \& Wetzel 1988). Growth rates obtained with the thymidine incorporation technique equalled a bacterial generation time of 9.9 and 4.5 d, respectively (Stns 13 and 24). This was at the higher limit of reported bacterial generation times in productive areas (10 to $100 \mathrm{~h}$; Hagström et al. 1979, Fuhrman \& Azam 1982). In this study the low TTI could not make up for the minimum growth estimate based on increase of bacterial numbers. As a consequence we use the measurement of predation on bacteria to estimate bacterial turnover in the energy flux model developed below.

The large copepod Calanus finmarchicus dominated the herbivore community at both Stns 13 and 24. Its pronounced diel vertical migration, high biomass and grazing capability are likely to have profound and different ecological effects at day and night on the surface mixed layer. Even though over $90 \%$ of daily grazing at both stations took place during the night, and in association with processes like sloppy feeding, excretion, defecation and respiration, the maximum excretion of copepods was too low to explain observed variations in ammonium concentrations (Table 1).

A striking difference between Stns 13 and 24 was the occurrence of the larger predator Paraeuchaeta norvegica at Stn 13. This station was clearly less productive than the other stations and herbivore biomass much lower. Nevertheless the diel variation was tremendous, manifested by high biomass of invertebrate predators and probably high predation on smaller copepods at night. This system resembled those in oligotrophic lakes where zooplanktivores depress herbivores. This might be a reason for the relatively small fraction of smaller copepods (<1 mm) at Stn $13(5 \%)$ compared to Stn 24 (25\%) (Tiselius 1988).

The grazing pressure exerted by the copepods at Stns 13 and 24 was considerably lower than at a coastal station in eastern Skagerrak, where more than twice the amount of chlorophyll was consumed daily by a copepod assemblage with a biomass $<30 \%$ of that at Stn 24 (Tiselius 1988). The small sizes of the algae $1>75 \%$ of biomass was $<10 \mu \mathrm{m}$ and $>36 \%<3 \mu \mathrm{m}$; Fig. 4) and the dominance of monads and flagellates probably reduced the copepods' significance as herbivores at both stations in the open Skagerrak. However, the higher biomass of 3-10 $\mu \mathrm{m}$ diatoms at Stn 24 (Fig. 4) was accompanied by a slightly higher weightspecific grazing rate of Calanus finmarchicus and more important, a doubling in its egg production rate compared to Stn 13.

Kiörboe et al. (1988) noted that egg production was correlated to chl a after water mixing events, but that no such correlation was observed prior to such events. Increased input of 'new' nutrients, increased cell size or change in the chemical composition of the algae were suggested as explanations. The impression of an earlier successional stage of the phytoplankton at Stn 24 might therefore be of significance for the egg production data. Thus, the algae at Stn 24 were not only more numerous but also of presumably higher nutritional value to the copepods, enabling them to produce more eggs from a given algal ration.

However, the different structure of the pelagic community cannot be explained by nutrient supply only. Nitrate concentrations in surface waters at both stations were similar; in fact they were higher in the stratified water of Stn 13, and therefore other factors, such as vertical stability or selective grazing, might be important. Furthermore, this shows that the structure of the pelagic food web does not seem to be governed by one single factor and that, in order to understand the trophic pathways, both physical and biological processes need to be investigated simultaneously. 


\section{Sedimentation and respiration}

Sedimentation rate as percentage of primary production was quite high for Stn 24 (87\%), while it was lower $(17$ and $21 \%$ ) for Stns 32 and 44 (Table 3). If sedimentation is equalled to new production (sensu Eppley \& Peterson 1979), new production (based on $\mathrm{NO}_{3}{ }^{-}$) was quite high at Stn 24 and lower at Stns 32 and 44 . This could be related to the comparatively higher $\mathrm{NO}_{3}{ }^{-}$ concentrations at Stn 24 compared to at Stns 32 and 44 . According to ${ }^{15} \mathrm{~N}$-studies percentage new production (= \% nitrate uptake of total $N$-uptake) above the pycnocline was 16 to $20 \%$ at Stns 32 and 44 (Fig. 6), which is similar to the percentage for new production based on sedimentation losses for these stations (no ${ }^{15} \mathrm{~N}$-measurements were made for Stn 24).

In Gullmarsfjord 'new' primary production ( $\approx$ sedimentation) was about $50 \%$ of a total production of ca $1 \mathrm{~g} \mathrm{C} \mathrm{m}^{-2} \mathrm{~d}^{-1}$. Compared to Stn 32 in the Skagerrak, which had a similar primary production, the percentage new production was substantially higher in Gullmarsfjord. Nitrate concentrations were also higher in the fjord (Table 6, Fig. 3C). To equate sedimentation and new production requires a steady state in the ocean surface. Over longer periods (e.g. 1 yr) such a steady state must exist, but a more precise minimum time scale for the coupling between 'new' production and sedimentation is difficult to give. Eppley et al. (1983), however, defined this time scale in days rather than weeks or months. It is thus advisable to be cautious when interpreting sediment trap data in the context of 'new' production. There are, however, other data supporting the conclusions with respect to the ratio of new to regenerated production, e.g. ${ }^{15} \mathrm{~N}$ uptake, phytoplankton community structure, and zooplankton grazing and egg production

Below-halocline respiration values (measured on unconcentrated samples) in the shallow SE Kattegat were generally below $1 \mathrm{ml} \mathrm{O}_{2} \mathrm{~m}^{-3} \mathrm{~h}^{-1}$ during April to July (W. Granéli unpubl.). For the deep water (> $60 \mathrm{~m}$ ) of the Baltic proper, Rahm (1987) calculated a mean annual respiration rate of $0.24 \mathrm{ml} \mathrm{O}_{2} \mathrm{~m}^{-3} \mathrm{~h}^{-1}$ below the halocline, i.e. a value similar to that found for Skagerrak deep water in May.

Integrating Skagerrak deep water oxygen uptake rates for a mean below-halocline water column of ca $200 \mathrm{~m}$ would lead to a carbon utilization rate of about $800 \mathrm{mg} \mathrm{C} \mathrm{m} \mathrm{m}^{-2} \mathrm{~d}^{-1}$, which is much larger than the measured sedimentation rate, and similar to the highest primary production value. Even in Gullmarsfjord the carbon equivalence of deep water respiration (also ca $800 \mathrm{mg} \mathrm{C} \mathrm{m} \mathrm{m}^{-2} \mathrm{~d}^{-1}$ ) was high compared to measured primary production and sedimentation values (ca 1000 and $500 \mathrm{mg} \mathrm{C} \mathrm{m}^{-2} \mathrm{~d}^{-1}$, respectively). These discrepancies may arise because (1) measured respiration and sedimentation values are overestimated (but see 'Methods'), (2) primary production, sedimentation and oxygen uptake are not in steady-state over such short periods as considered here (see Eppley et al. 1983), (3) primary production is underestimated, (4) there are additional carbon sources beside new primary production in the water column or (5) lateral transport of organic carbon is significant.

According to van Weering et al. (1987), the Skagerrak is the main deposition area for the North Sea, although it is not clear from their work whether particulate organic matter enters Skagerrak along the bottom (in which case it would not influence our respiration measurements) or if lateral carbon input occurs in the water mass considered here, i.e. $<100$ m. Eisma \& Kalf (1987) found that suspended matter concentrations in the bottom water are similar to those in the surface and that velocity of the currents going into Skagerrak can be up to $15 \mathrm{~cm}$ $\mathrm{s}^{-1}$ down to $100 \mathrm{~m}$ water depth (Rodhe 1987). It can be noted that an unbalance between carbon input and respiration has also been found by others, e.g. in the North Sea by Joiris et al. (1982).

\section{Benthos}

The sediments at the stations in the open Skagerrak were different in structure, organic content and benthic faunal composition, mirroring differences in deposition of sedimenting material and food conditions. Thus, heterogeneity was not only found in the pelagic system, which could be of short-term nature, but also in the benthic system, indicating spatial heterogeneity of a long-term nature. Results from Josefson (1985) showed greater similarities within sediments and benthic communities at about the same depth in the eastern Skagerrak.

The high organic content in the sediments at Stn 44 was not correlated to a similarly higher sedimentation rate at that station. Such a correlation cannot be expected from short-term sedimentation studies and, moreover, bottom currents may affect the advective distribution and subsequent accumulation of material.

\section{Energy flux in the pelagic food web}

Total pelagic $(0$ to $15 \mathrm{~m}$ ) respiration. in the open Skagerrak at Stns 13 and 24 was 303 and $532 \mathrm{mg} \mathrm{C} \mathrm{m}^{-2}$ $\mathrm{d}^{-1}$ (Table 8). We will in the following evaluate the contribution of different groups of organisms to this respiration. It is evident from the net-zooplankton data that their metabolic activity could only account for $<1 \%$ of the total respiration. Although no results are available for micro-zooplankton their respiration is not 
Table 8. Carbon budget for Stns 13 and 24. All values are in $\mathrm{mg} \mathrm{C} \mathrm{m}^{-2} \mathrm{~d}^{-1}$. Bacterial growth demand was based on the grazing estimates assuming balance against bacterial production. See text for details

\begin{tabular}{|cccccc|}
\hline Station & $\begin{array}{c}{ }^{14} \mathrm{CO}_{2} \\
\text { fixation }\end{array}$ & $\begin{array}{c}\mathrm{O}_{2} \\
\text { consumption }\end{array}$ & $\begin{array}{c}\text { Bacterial } \\
\text { assimilation }\end{array}$ & $\begin{array}{c}\text { Flagellate } \\
\text { respiration }\end{array}$ & $\begin{array}{c}\text { Bacterial } \\
\text { respiration }\end{array}$ \\
\hline 13 & 160 & 303 & $267^{\mathrm{a}}$ & $70^{\mathrm{a}}$ & $107^{\mathrm{a}}$ \\
24 & 325 & 532 & $593^{\mathrm{a}}$ & $237^{\mathrm{a}}$ & \\
${ }^{a}$ Calculated values & & & & \\
\hline
\end{tabular}

considered to have been significant since less than 1 ciliate $\mathrm{ml}^{-1}$ was observed in the flagellate counts.

Due to the reasons outlined earlier, we choose to use the estimate of predation on bacteria as a measure of the turnover of the bacterial community. Bacterial growth was roughly balanced by predation, since no systematic changes in bacterial abundance during the experiments were observed.

As shown in 'Results', the bacterial growth demand of carbon exceeded the primary production at Stns 13 and 24. Difficulties with supporting measured bacterial turnover with enough organic material have previously been reported (e.g. Joiris et al. 1982, Scavia \& Laird 1987. Hagström et al. 1988) and may not be erroneous. Firstly, high microbial activity predominating during the photosynthetically active period might by itself cause an underestimation of primary production by the ${ }^{14} \mathrm{C}$-incubation method. Respiration and reassimilation of ${ }^{14} \mathrm{C}$ atoms by microorganisms might not be negligible during the ${ }^{14} \mathrm{C}$-incubation. A total of 62 and $24 \%$ (Stns 13 and 24, respectively) carbon fixation was due to organisms $<10 \mu \mathrm{m}$, showing that a substantial part of the fixed $\mathrm{CO}_{2}$ was readily available to the nanoplankton heterotrophs. Secondly, dissolved nutrients are not only derived directly from algae, but also from grazing protozoans and larger zooplankton (Fenchel 1982b, Caron et al. 1985, Hagström et al. 1988).

The estimated respiration of bacteria and flagellates together made up approximately 110 to $120 \%$ of the net primary production. Thus, from the data it seems that the net production of algal biomass will be too scarce for the assimilation of the secondary producers. It must be realized, however, that carbon can be assimilated several times and that, consequently, consumer assimilation can largely exceed primary production (e.g. Strayer 1988).

\section{GENERAL CONCLUSIONS}

An attempt was made to give a synoptic description of the pelagic community in the Skagerrak and its relationship to physical and chemical factors important to the cycling of mineral nutrients. It is evident from the present paper that even with a massive input of scientific expertise the complexity of the pelagic ecosystem is too great and the methodology insufficient to give a detailed account of the flux of nutrients in the sea. However, our results do suggest:

- that most of the nitrogen used by primary production was regenerated nitrogen;

- that the apparent discrepance between autotrophic and heterotrophic production was due to rapid reuse of assimilated carbon biasing the ${ }^{14} \mathrm{C}$-primary production estimate;

- that the great reservoir of nutrients below the pycnocline could be used by phytoplankton and partly returned to the surface by migrating algae;

- that the loss of nutrients through sedimentation at least partly could be compensated through vertical migration of the algae;

- that the microbial size fraction dominated the overall heterotrophic activity in the euphotic zone;

- that the percent of 'new' production was similar when estimated from ${ }^{15} \mathrm{~N}$-uptake studies and from sedimentation losses;

- that in coastal areas a larger proportion of the primary production is likely to be lost through the pycnocline; this production is supported by supply of 'new' nutrients from land run-off.

Acknowledgements. We thank the crew on RV 'Argos' and P.O. Skoglund for excellent assistance during the cruise. Financial support for this study was given by the Swedish Environment Protection Board and 'Nordisk Kulturfond'.

\section{LITERATURE CITED}

Ertebjerg, G., Bresta, A.-M. (1984). Guidelines for the measurements of phytoplankton primary production. Baltic Marine Biologists (BMB) Publ. No. 1 (2nd ed.): 1-23

Baltic Marine Biologists (1976). Recommendations on methods for marine biological studies in the Baltic Sea. Baltic Marine Biologists (BMB) Publ. No. 1 1-98

Bergquist, A. M., Carpenter, S. R. (1986). Limnetic herbivory: effects on phytoplankton populations and primary production. Ecology 67: 1351-1360

Blackburn, T. H., Henriksen, K. (1983). Nitrogen cycling in different types of sediments from Danish waters. Limnol. Oceanogr 28: $477-493$ 
Bratbak, G., Dundas, I. (1984). Bacterial dry matter content and biomass estmmations. Appl. environ. Microbiol 48: $755-757$

Buchanan, J. B., Kain, J. M. (1971). Measurement of the physical and chemical environment. In: Holme, N. A., Mcintyre, A. D. (eds.) Methods for the study of marine benthos. Blackwell, Oxford, p. 30--58

Button, D. K. (1985). Kinetics of nutrient-limited transport and bacterial growth. Microbiol. Rev. 49: 270-297

Carlberg, S. (1972). New Baltic manual. Int. Counc. Explor Sea Comm. Meet. (Coop. Res. Rep. Ser. A) 29: 57-90

Caron, D. A., Goldman, J. C., Andersen, K. O., Dennett, M. R. (1985). Nutrient cycling in a microflagellate food chain. II. Population dynamics and carbon cycling. Mar. Ecol. Prog. Ser. 24: 243-254

Cornett, R. J., Rigler, F. H. (1986). Simple method of measuring seston respiration in oligotrophic lakes. Can. J. Fish. Aquat. Sci. 43: 1660-1663

Coveney, M. F., Wetzell, R. G. (1988). Experimental evaluation of conversion factors for the ${ }^{3} \mathrm{H}$-thymidine incorporation assay of bacterial secondary productivity. Appl. environ. Microbiol. 54: 2018-2026

Dahl, E., Danielssen, D. S. (1981). Hydrography, nutrients and phytoplankton in the Skagerrak along the section Torungen-Hirtshals, January-June 1980. In: Satre, R., Mork, M. (eds.) The Norwegian coastal current. University of Bergen, Bergen, p. 294-310

Davis, P. G., Sieburth, J. McN. (1984). Estuarine and oceanic microflagellate prectation of actively growing bacteria. Estimation by frequency of dividing/divided bacteria. Mar Ecol. Prog. Ser 19: 237-246

Edler, L. (ed.) (1979). Recommendations on methods for marine biological studies in the Baltic Sea; phytoplankton and chlorophyll. Baltic Marine Biologists (BMB) Publ. No. 5: 1-38

Eisma, D., Kalf, J. (1987). Dispersal, concentration and deposition of suspended water in the North Sea. J. geol. Soc. Lond. 44: 161-178

Eppley, R. W., Peterson, B. J. (1979). Particulate organic matter flux and planktonic new production in the deep ocean. Nature, Lond 282: 677-680

Eppley, R. W.. Renger, E. H., Betzer, P. R. (1983). The residence time of particulate organic carbon in the surface layer of the ocean. Deep Sea Res. 30: 311-323

Fenchel, T (1982a). Ecology of heterotrophic microflagellates. II. Bioenergetics and growth. Mar Ecol. Prog. Ser. 8: 225-231

Fenchel, $T$ (1982b). Suspended marine bacteria as a food source. In: Fasham, M. J. R. (ed.) Flows of energy and materials in marine ecosystems. Plenum Press, New York, p. $301-316$

Fuhrman, J. A., Azam, F. (1982). Thymidine incorporation as a measure of heterotrophic bacterioplankton production in marine surface waters: evaluation and field results. Mar Biol. 66: 109-120

Fuhrman, J. A., Eppley, R. W., Hagström, \&., Azam, F. (1985). Diel variation in bacterioplankton, phytoplankton, and related parameters in the Southern Cahifornia Bight. Mar Ecol. Prog. Ser 27: 9-20

Foyn, L. (1987). Neeringssalt i Nordsjøen og Skagerrak. Nordforsk Miljôvårdserien publ. 1987 (1): 133-146

Hagström, A., Azam, A., Andersson, A., Wikner, J., Rassoulzadegan, F. (1988). Microbial loop in an oligotrophic pelagic marine ecosystem: possible roles of cyanobacteria and nanoflagellates in the organic fluxes. Mar. Ecol. Prog. Ser. 49: 171-178

Hagström, A., Larsson, U. (1984). Diel and seasonal variation in growth rates of pelagic bactena. In: Hobbie, J. E., Williams, P. J, LeB. (eds.) Heterotrophic activity in the sea. Plenum Press, New York, p. 249-262

Hagström, A., Larsson, U., Hörstedt, P., Normark, S. (1979). Frequency of dividing cells, a new approach to the determination of bacterial growth rates in aquatic environments Appl. environ. Microbiol. 37: 805-812

Håkanson, L. (1984). Suspension and calibration of a sediment trap. Schweiz. Z. Hydrol 46: 171-175

Holligan, P. M., Williams, P. J. LeB., Purdie, D., Harris, R. P. (1984). Photosynthesis, respiration and nitrogen supply of plankton populations in stratified, frontal and tidally mixed shelf waters. Mar. Ecol. Prog. Ser. 17: 201-213

Jansson, M. (1976). Phosphatases in lake water. Characterisation of enzymes from phytoplankton and zooplankton by gel filtration. Science 194: 320-321

Joiris, C., Bille, G., Lancelot, C., Daro, M. H., Mommaerts, J. P., Bertels, A., Bossicart, M., Nijs, J., Hecq, J. H. (1982). A budget of carbon cycling in the Belgian coastal zone: relative roles of zooplankton, bacterioplankton and benthos in the utilization of primary production. Neth. J. Sea Res. 16: 260-275

Josefson, A. B. (1985). Distribution of diversity and functional groups of marine benthic infauna in the Skagerrak (eastern North Sea) - Can larval availability affect diversity? Sarsia 70: 229-249

Kiörboe, T., Möhlenberg, F., Riisgård, H. U. (1985). In situ feeding rates of planktonic copepods: a comparision of four methods. J. exp. mar. Biol. Ecol. 88: 67-81

Kiörboe, T., Möhlenberg, F., Tiselius, P. (1988). Propagation of planktonic copepods: production and mortality of eggs. Hydrobiologia 167/168: 219-225

Larsson, A.-M., Rodhe, J. (1979). Hydrographical and chemical observations in the Skagerrak 1975-1977. Report no. 29. Oceanografiska inst. Univ. Göteborg, Göteborg

Larsson, U., Hagström, $\AA$ (1982). Fractionated phytoplankton primary production exudate release and bacterial production in a Baltic eutrophication gradient. Mar Biol. 67: $57-70$

Lee, S, Fuhrman, J. A. (1987). Relationships between biovolume and biomass of naturally derived marine plankton. Appl environ. Microbiol. 53: 1298-1303

Newell. R. C., Linley, E. A. S. (1984). Significance of microheterotrophs in the decomposition of phytoplankton: estimates of carbon and nitrogen flow based on the biomass of plankton communities. Mar Ecol. Prog. Ser. 16: $105-11.9$

Nyman, E., Granéli, E. (1983). Alkaline phosphatase activity in the Laholm Bay, South-Eastern Kattegat. Sarsia 68: $275-279$

Payne, W. J. (1970). Energy yields and growth of heterotrophs. A. Rev. Microbiol. 24: 17-52

Petersson, K. (1979). Enzymatic determination of orthophosphate in natural waters. Int. Revue ges. Hydrobiol. 64 $585-607$

Pielou, E. C. (1966). Species-diversity and pattern diversity in the study of ecological succession. J. theor. Biol. 10 $370-383$

Pingree, R. D., Holligan, P. M., Mardell, G. T., Harris, R. P (1982). Vertical distribution of plankton in the Skagerrak in relation to doming of the seasonal thermocline. Cont Shelf Res. 1: 209-219

Porter, K. G. (1976). Enhancement of algal growth and productivity by grazing zooplankton. Science 192: 1332-1334

Porter, K. G., Feig. Y. S. (1980). The use of DAPI for identifying and counting aquatic microflora. Limnol. Oceanogr 25: $943-948$ 
Rahm, L. (1987). Oxygen consumption in the Baltic proper Limnol. Oceanogr 32: 973-978

Richardson, K. (1985). Plankton distribution and activity in the North Sea/Skagerrak-Kattegat frontal area in April 1984 Mar Ecol. Prog. Ser. 26: 233-244

Riemann, B., Björnsen, P. K., Newell, S., Fallon, R. (1987). Calculation of cell production of coastal marine bacteria based on measured incorporation of ${ }^{3} \mathrm{H}$-thymidine. Limnol. Oceanogr 32: 471-476

Riemann, B., Söndergaard, M. (1984). Measurements of diel rates of bacterial secondary production in aquatic environments. Appl. environ. Microbiol. 47: 632-638

Rodhe, J. (1987). The large-scale circulation in the Skagerrak; interpretation of some observations. Tellus 39 A: 245-253

Sahlsten, E., Sörensson, F., Pettersson, K. (1988). Planktonic nitrogen uptake in the south-eastern Kattegat. J. exp. mar Biol. Ecol. 121: 227-246

Scavia, D., Laird, G. A. (1987). Bacterioplankton in Lake Michigan: dynamics, controls and significance to carbon flux. Limnol. Oceanogr. 32: 1017-1033

Sieburth, J. McN., Johnson, K. M., Burney, C. M., Lavole, D. M. (1977). Estimation of in situ rates of heterotrophy using diurnal changes in organic matter and growth rates of picoplankton in diffusion culture. Helgoländer Meeresunters. 30: 565-574

Sievens, R. J., Parr, M. P. (1977). The significance of alkaline phosphatase activity in Lough Neagh. Freshwat. Biol. 7: 351-355

Strayer, D. (1988). On the limits to secondary production. Limnol. Oceanogr. 33: 1217-1220

Svansson, A. (1975). Physical and chemical oceanography of the Skagerrak and the Kattegat. Fish. Board Swed., Inst. Mar. Res. Rep. 1: 1-88

Tiselius, P. (1988). Effects of diurnal feeding rythms, species composition and vertical migration on the grazing impact

This article was submitted to the editor of calanoid copepods in the Skagerrak and Kattegat. Ophelia 28: 215-230

Valderrama (1981). The simultaneous analysis of total nitrogen and total phosphorus in natural waters. Mar Chem. 10: 109-122

van Weering, T C. E., Berger, G. W., Kalf, J. (1987). Recent sediment accumulation in the Skagerrak, northeastern North Sea. Neth. J. Sea Res. 21. 177-189

Veldhuis, M. J. W., Venekamp, L. A. H., Ietswaard, T (1987). Availability of phosphorus sources for blooms of Phaeocystis pouchetii (Haptophyceae) in the North Sea: impact of the river Rhine. Neth. J. Sea Res. 21. 219-229

Wassmann, P. (1983). Sedimentation of organic and inorganic particulate material in Lindaspollene, a stratified, landlocked fjord in western Norway. Mar. Ecol. Prog. Ser. 13: $237-248$

Wassmann, P. (1984). Sedimentation and benthic mineralization of organic detritus in a Norwegian fjord. Mar. Biol. 83: 93-94

Wassmann, P. (1986). Benthic nutrient regeneration as related to primary productivity in the west-Norwegian coastal zone. Ophelia 26: 443-456

Wikner, J., Andersson, A., Normark, S., Hagström, $\AA$. (1986). Genetically marked minicells, a probe in measurement of predation on bacteria in aquatic environments. Appl. environ. Microbiol. 52: 4-8

Wikner, J., Hagström, $\AA$. (1988). Evidence for a closely coupled nanoplanktonic predator-prey link regulating bacterivores in the marine environment. Mar. Ecol. Prog. Ser. 50: 137-145

Wikner, J., Rassoulzadegan, F., Hagström, $\AA$. (1990). Periodic bacterivore activity balances bacterial growth in the marine environment. Limnol. Oceanogr (in press)

Wynne, D. (1981). The role of phosphatases in the metabolism of Peridinium cinctum, from Lake Kinneret. Hydrobiologia 83: 93-99

Manuscript first received: May 12, 1989

Revised version accepted: December 19, 1989 